\title{
EL CONCEPTO DE LEGADO EN EL DERECHO CIVIL CHILENO
}

\author{
Alejandro Guzmán Brito*
}

\section{RESUMEN}

El artículo propone definir un legado como "la gratuita, liberal y lucrativa atribución o extinción por causa de muerte de un derecho real o personal, manifestada a título singular en un testamento por su autor o prescrita de la misma manera por la ley, a favor de una persona llamada legatario"; y explica cada uno de los conceptos empleados en tal definición.

\section{LEGADO - ASIGNACIÓN POR CAUSA DE MUERTE - LIBERALIDAD}

\section{The concept of legacy in Chilean law}

\begin{abstract}
The article proposes to define a legacy as "the free, liberal and lucrative attribution or extinction by cause of death of a real or personal right, manifested in a testament for its author or in the same manner prescribed by law, in favour of a person named legatee"; and explains each of the concepts used in this definition.
\end{abstract}

LEGACY - ASSIGNATION BY CAUSE OF DEATH - LIBERALITY

* Abogado, Doctor en Derecho, profesor titular de Derecho romano de la Facultad de Derecho de la Pontificia Universidad Católica de Valparaíso., Avenida Brasil 2950, Valparaíso, aguzman@ucv.cl. Artículo recibido el 16 de mayo de 2008 y aceptado para su publicación por el Comité Editorial el 24 de octubre de 2008. 


\section{INTRODUCCIÓN TERMINOLÓGICA**}

1. En torno a la figura central del legado, el Código Civil ofrece una terminología algo variada. En su artículo 951 inciso $3^{\circ}$ habla de suceder a un difunto "a título singular", en oposición a sucederle a título universal; su artículo 954 establece que las "asignaciones a título singular" se llaman "legados"; y que el "asignatario de legado" se llama "legatario"; en el artículo 1066 inciso $1^{\circ}$, aunque su contenido es en parte coincidente con el del artículo 951 inciso $3^{\circ}$, la figura opuesta a la ahí mencionada de "asignación a título universal", que es "asignación a título singular", resulta omitida; pero en el artículo 1140 inciso $1^{\circ}$, no bien encabece éste el $\S$ 6: De las asignaciones a título singular, el Código se refiere a los "asignatarios a título singular" y esta expresión es considerada sinónima de "legatarios". El sustantivo "legado" -lo mismo que "legatario"- se presenta frecuentemente en el mencionado § 6; y también el verbo "legar" en sus diferentes conjugaciones, tanto como el adjetivo verbal "legado/a"; lo propio acaece en disposiciones diseminadas a lo largo del cuerpo legal. Nunca, empero, comparece la expresión "sucesión a título singular".

Sin embargo, ni las variedades terminológicas ni las ausencias mueven a incertidumbres de especie alguna.

Para el Código, quien conoce un modo de adquirir el dominio designado como "sucesión por causa de muerte" (artículo 588 y rúbrica de su libro III), existe una especie de ésta que llamamos "sucesión por causa de muerte a título singular", como podemos colegir del artículo 951: "Se sucede a una persona difunta a [...] título singular", en cabeza del libro III, rubricado precisamente: De la sucesión por causa de muerte [...]. La operación formal de esta especie del modo general se denomina "asignación (por causa de muerte) a título singular" que es lo mismo que "legado"; de donde la terminología correlativa de "sucesor por causa de muerte a título singular", "asignatario (por causa de muerte) a título singular", o "asignatario de legado" o "legatario".

En este trabajo nos concentraremos en la operación del modo, vale decir, en la asignación por causa de muerte a título singular o legado.

** Abreviaturas: Claro Solar, Luis, Explicaciones, XV, 3 = Claro Solar, Luis, Explicaciones de Derecho civil chileno y comparado, XV: De la sucesión por causa de muerte, 1942, reimpresión Santiago, Editorial Jurídica de Chile, 1992, VII; Domínguez, R. / Domínguez, R., Der. suc. = Domínguez Benavente, Ramón-Domínguez Águila, Ramón. Derecho sucesorio, $2^{a}$ edición, Santiago, Editorial Jurídica de Chile, 1998; Elorriaga, F., Der. suc. = Elorriaga de Bonis, Fabián, Derecho sucesorio, Santiago de Chile, LexisNexis, 2005; Meza Barros, R., Manual = Meza Barros, Ramón, Manual de la sucesión por causa de muerte y de las donaciones entre vivos, $8^{\text {a }}$ edición, Santiago, Editorial Jurídica de Chile, 2007; Rodríguez Grez, P., Inst. Der. suc. = Rodríguez Grez, Pablo., Instituciones de Derecho sucesorio, 2a edición, Santiago de Chile, Editorial Jurídica de Chile, 2002; Somarriva, M., Der. suc. = Somarriva Undurraga, Manuel, Derecho sucesorio, $6^{a}$ edición, Santiago, Editorial Jurídica de Chile, 2003. 
2. Pero la palabra "legado" es ambigua:

i) En ocasiones designa un acto jurídico, que la ley denomina asimismo "asignación a título singular" (artículo 954 CC.), y en tal sentido es empleada en muchas disposiciones del Código; así, por ejemplo, en su artículo 1105: "No vale el legado de cosa incapaz de ser apropiada, según el artículo 585 [...]"; o en el artículo 1107 CC.: "El legado de especie que no es del testador, o del asignatario a quien se impone la obligación de darla, es nulo"; o en el artículo 1135 inciso $2^{\circ}$ CC.: "La enajenación de las especies legadas, en todo o parte, por acto entre vivos, envuelve la revocación del legado, en todo o parte"; etcétera;

ii) A veces denota el objeto del acto, vale decir, el objeto legado, como en el artículo 967 CC.: "El incapaz no adquiere la herencia o legado, mientras no prescriban las acciones que contra él puedan intentarse por los que tengan interés en ello", pues, en efecto, no se podría interpretar que el término "legado" significa aquí el acto jurídico, puesto que los actos jurídicos no se adquieren: la norma dice, por consiguiente, que el incapaz no adquiere el objeto legado mientras no prescriban las acciones, etcétera; también en el artículo 974 CC.: "Declarada judicialmente (sc. la indignidad del asignatariof, es obligado el indigno a la restitución de la herencia o legado con sus accesiones y frutos", porque no se trata de la restitución del acto sino del objeto de ese acto, que el indigno había adquirido y ahora, en efecto, debe restituir; también en el artículo 975 CC.: "La indignidad se purga en cinco años de posesión de la berencia o legado", pues no se atañe a la posesión del acto sino al objeto legado; etcétera;

iii) La palabra también puede mentar un efecto, precisamente aquel producido por el acto sobre su objeto; así en el artículo 1290 CC.: "Pagará [sc. el albacea] los legados que no se hayan impuesto a determinado heredero o legatario", porque lo impuesto no es ni el acto ni el objeto de éste, sino la obligación de cumplir emanada del acto, vale decir, su efecto; o en el artículo 1373 inciso $2^{\circ}$ CC.: "Si en la partición de una herencia se distribuyeren los legados entre los herederos de diferente modo, podrán los legatarios entablar sus acciones, o en conformidad a esta distribución, o en conformidad al artículo 1360, o en conformidad al convenio de los herederos", ya que en el caso previsto no se alude a una distribución de las cosas legadas ni menos de los actos, sino de las obligaciones de cumplir los legados.

iv) No faltan casos en que la palabra aparece dinámicamente usada en más de un sentido, como en el artículo 1293 CC.: "Con anuencia de los herederos presentes [sc. el albacea] procederá a la venta de los muebles, y subsidiariamente de los inmuebles, si no bubiere dinero suficiente para el pago de las deudas o de los legados", porque la expresión "los legados" tanto significa los objetos legados cuanto la obligación impuesta por las asignaciones.

En este trabajo, por regla generalísima usamos el término "legado" en su sentido de acto y de efecto del acto. 


\section{LA DEFINICIÓN DEL LEGADO}

Ofreceremos ya preliminarmente nuestra definición del legado, bajo el cual entendemos "la gratuita, liberal y lucrativa atribución o extinción por causa de muerte de un derecho real o personal, manifestada a título singular en un testamento por su autor o prescrita de la misma manera por la ley, a favor de una persona llamada legatario”.

Cuanto sigue en este trabajo está destinado a explicar las nociones empleadas en la definición que antecede, aunque no siempre conforme con el mismo orden de comparecencia en ella.

Por lo demás, ya en esta sede podemos despachar rápidamente una de tales nociones, que en la definición viene aludida con recurso al verbo "manifestar", el cual vale por "declarar o manifestar la voluntad" y por la mención del testamento.

El legado, cuando no va dispuesto por la ley, es en sí mismo un acto jurídico y, como tal, pues, una declaración o manifestación de voluntad. Pero carece de forma propia, autónoma e independiente y para su perfección es menester incrustarlo en alguna forma reconocida como testamentaria por la ley, que a su vez también ofrece la naturaleza de acto jurídico. La cual forma admite otro actos jurídicos, como las disposiciones a título universal o herencias, el nombramiento de tutores y curadores, la confirmación, en ciertos casos, de donaciones revocables, el desheredamiento, el reconocimiento o confesión de deudas, el reconocimiento de hijo, el nombramiento de albacea y el de partidor, la revocación total de otro testamento, la revocación de disposiciones de otro testamento sin afectar al resto de éste, etcétera, ninguno de los cuales admite su designación por medio del término "legado". De esta manera, menester es distinguir el acto jurídico constituido por la forma testamentaria de los diversos actos jurídicos sustanciales que ésta alberga, entre ellos el legado, lo cual se aprecia máximamente por la consideración de que la nulidad de tales actos individualmente considerados no importa la de los demás ni la del testamento, aunque la de éste sí envuelva la nulidad de todos los actos que acoge, mas por constituir la forma común de todos, no por confundirse o consistir en ellos. El testamento, pues, no es un acto jurídico sustancial el mismo, ya que es una pura forma, ni es la suma de los actos jurídicos sustanciales (legados, herencias, etcétera) que contiene. Tampoco los actos jurídicos que requieren la forma testamentaria son ellos mismos el testamento. Ahora bien, algunos de los actos jurídicos que dan contenido al testamento, necesariamente deben adoptar la forma testamentaria y tal es el caso del legado; vale decir, el acto jurídico llamado "legado" sólo puede ser dispuesto en un testamento, ${ }^{1}$ a diferencia, por ejemplo, del nombramiento de tutor, que puede ser por sentencia judicial (artículo 353 inciso $4^{\circ}$ CC.) o el reconocimiento de hijo, que puede ser por escritura pública (artículo 187 No 3 CC.). o por acta pública del Registro Civil

${ }^{1}$ Una leve dificultad a esta afirmación se presenta con las donaciones por causa de muerte dispuestas según las solemnidades de aquellas entre vivos, en que el testador se reserva la facultad de revocarlas (artículo 1137 CC.). Aparentemente, pues, la forma testamentaria hace defecto en ellas, pese a tratarse de legados anticipados (artículo 1141 CC.). Pero el propio artículo 1137 inciso $2^{\circ}$ CC. salva la dificultad, cuando, para la subsistencia de la donación, exige su confirmación expresa en acto testamentario, así que la validez final de estas donaciones arranca de tal acto. 
(artículo $187 \mathrm{~N}^{\circ} 2$ CC.), etcétera. Lo cual significa que el legado no es formalmente un acto jurídico sino a través de la forma testamentaria; pero que una vez adoptada, se distingue sustancialmente de ella, como acto jurídico aparte.

La autonomía sustancial del legado en cuanto acto jurídico, pues, se subraya con el uso del verbo "manifestar" y su dependencia formal del testamento, con la mención del mismo.

Sin embargo, hemos optado por no situar al acto jurídico como género próximo de la definición, y en vez de decir tratarse él, por ejemplo, del "acto jurídico contenido en un testamento", etcétera, hemos situado al efecto en el lugar de tal género: "la [...] atribución o extinción”, etcétera. La razón es que a veces el legado no consiste en un acto jurídico, como en el caso de los legados legales o dispuestos por la ley, de que trataremos dentro de poco. ${ }^{2}$ En tal hipótesis, pues, legado se toma en su sentido de efecto (producido por la ley); y como el efecto sí que es común al legado-acto y al legado dispuesto por la ley, he ahí la licitud de instalar precisamente al efecto en calidad de género próximo de la definición

\section{LA CAUSA DE MUERTE Y LA INEXISTENCIA DE LEGADOS ENTRE VIVOS}

Queda también preliminarmente en claro que el legado sólo es posible por causa de muerte. La definición señala expresamente tal idea, que, además, resulta destacada por efecto del papel que se asigna al testamento -un ejemplo típico de acto por causa de muerte- con respecto a los legados cuando son actos jurídicos. ${ }^{3}$

El artículo 953 inciso $1^{\circ} \mathrm{CC}$. denomina "asignaciones por causa de muerte" a las que hace la ley o el testamento de una persona difunta para sucederle en sus bienes; el inciso $2^{\circ}$ del mismo artículo declara que "asignación" es lo mismo que "asignación por causa de muerte"; y el artículo 954 CC. expresa que las "asignaciones (es decir, por causa de muerte) a título singular" se llaman "legados”. No hay, pues, legados entre vivos.

a) Aparentemente entorpece esta afirmación la existencia de la figura que el Código denomina "donación revocable", identifica plenamente con la "donación por causa de muerte" (artículo 1136 inciso $2^{\circ}$ ) y considera como "legado anticipado" si es a título singular (artículo 1141). La dificultad proviene de que cuando el donante hace seguir la entrega de las cosas donadas al acto donatorio, se da lugar a un efecto entre vivos, que el artículo 1140 inciso $1^{\circ}$ CC. describe como adquisición de los derechos y contraimiento de las obligaciones de usufructuario. ${ }^{4}$ De esta guisa, la donación revocable

\footnotetext{
${ }^{2}$ Véase, más abajo, el capítulo IV.

${ }^{3}$ Por lo cual no hay redundancia, ya que los legados dispuestos por la ley también lo son por causa de muerte, carácter que, obviamente, no les viene de haber un testamento de por medio.

${ }^{4}$ Como puede observarse, la norma no dice que se constituye un usufructo, precisamente porque sólo atribuye los derechos y obligaciones de éste al donatario; y de la diferencia entre ambas formulaciones podrían tal vez extraerse algunas consecuencias, en orden, por ejemplo, a negar cualquier otra aplicación del estatuto del usufructo a la donación revocable seguida de la entrega de lo donado, que no pertenezca
} 
a título singular seguida de la entrega de las cosas donadas sería un legado entre vivos, por producirse en el caso un efecto que de ningún modo puede considerarse por causa de muerte, ya que tiene lugar inmediatamente y en vida del donante.

Pero se trata de un espejismo. Que el efecto de atribución de los derechos y obligaciones de usufructuario al donante es un efecto entre vivos, de eso no cabe ni siquiera dudar. Pero ese efecto no viene del acto donatorio sino de la ley, precisamente del artículo 1140 inciso $1^{\circ} \mathrm{CC}$., el cual pone su atención en el hecho no estructural de la donación, y meramente accidental y contingente, como es la entrega entre vivos de las cosas donadas, para convertir lo que hubiera sido nada más que algo semejante a un precario en una situación jurídica descrita como ya sabemos, vale decir, de derechos y obligaciones de usufructuario. Por lo que a la donación en sí misma atañe, su efecto adquisitivo del dominio sigue siendo a causa de muerte, pues sólo al morir el donante, sin haber revocado la donación y habiéndola confirmado, cuando se exige este requisito, es que el donatario adquiere el dominio de tales cosas (artículo 1144 CC.), como en todos los legados de efecto dominical. ${ }^{5}$ No puede, pues, decirse que es un legado el que

rigurosamente al de derechos y obligaciones de usufructuario. Por ejemplo, alguien podría pretender negar que resultare aplicable el artículo 769 CC., que prohíbe constituir dos o más usufructos sucesivos, porque el contenido de esa norma no atañe a derechos y obligaciones de usufructuario, sino a limitaciones dirigidas al constituyente, que, por ende, tocan al acto mas no a sus efectos. Supóngase a un donante que dijera: "dono revocablemente tal cosa a Ticio, y una vez muerto, se la dono, de la misma manera, a Cayo"; y acto seguido entregara a Ticio la cosa donada. Es claro que el efecto de esta operación no puede ser que, una vez confirmada la donación revocable en cabeza de Ticio por la muerte de su donante sin haberla revocado (artículo 1144 CC.), al morir Ticio el objeto del cual se trata se hace de Cayo, porque ese objeto ingresó en el dominio pleno de Ticio, y como tal hace parte de su sucesión normal. Si se pretendiera que el objeto debe pasar a Cayo, se contravendría al artículo 1463 CC., pues por la donación revocable original se estaría disponiendo del derecho de suceder por causa de muerte a una persona viva, o sea, a Ticio. La figura que proponemos a examen es otra y se refiere, no al dominio de la cosa donada adquirido por el donatario una vez fallecido el donante que no revocó, sino a los derechos y obligaciones de usufructuario adquiridos inmediatamente y entre vivos sobre la cosa donada por el donatario a quien le entregó aquélla el donante. Si el donatario fallece antes que el donante, en principio, como es sabido, la donación caduca (artículo 1143 CC.); pero como el donante declaró: “[...] y una vez muerto, se la dono, de la misma manera, a Cayo”, eso vale como una sustitución, que no hay razones para declarar improcedente en las donaciones revocables. En tales circunstancias, los derechos y obligaciones de usufructuario pasarían a Cayo una vez muerto Ticio (y ha de ser que aquél adquirirá el dominio al fallecer el donante sin haber revocado la donación), en su calidad de donatario sustituto. El ejemplo se podría completar con varias sustituciones de grado ulterior. Ahora bien, si consideramos la figura como un usufructo y lo observamos desde el punto de vista del donante, el efecto es la constitución de usufructos sucesivos, destinados a pasar a distinta persona una vez muerto el usufructuario anterior, que es lo que el artículo 769 CC. impide. Pero como el artículo 1140 CC. no dice que en el caso en examen hay un usufructo, el antes citado no le sería aplicable; y tendríamos ahí un caso, no de usufructos sucesivos, pero sí de adquisición sucesiva de derechos y obligaciones de usufructuario. Se observará, con todo, que, como al morir el donante cesa, según antes quedó dicho, la sucesión, porque el último donatario se hace dueño pleno de la cosa donada, la razón que justifica el artículo 769 CC., que es impedir la perpetua separación del usufructo y la nuda propiedad, no se da en la figura que acabamos de examinar. De todos modos, no es el momento de ahondar en el punto y, para el análisis conducido en el texto, resulta suficiente mantenernos en la ya dicha formulación que emplea el Código.

${ }^{5}$ Como es sabido, en los legados normales es necesaria la aceptación post mortem testatoris y pueden ser repudiados (artículos 1224 y 1226 CC.). ¿Cómo operan estas facultades en las donaciones revocables con 
ha atribuido los derechos y obligaciones de usufructuario al donatario-legatario, que significaría aceptar que un legado puede producir efectos entre vivos.

Algo semejante hay que decir cuando tiene lugar la situación inversa a la precedentemente tratada; esto es, cuando la persona, que en su testamento ha asignado un legado de ciertas cosas a otra, entrega en vida el goce de tales cosas al legatario. En tal hipótesis, la figura deviene en donación revocable y el legatario, ahora donatario, también adquiere por ley los derechos y obligaciones de usufructuario (artículo 1141 inciso $2^{\circ}$ CC.); pero no el dominio, que sólo recibirá por causa de muerte una vez fallecido el testador-donante, merced al legado.

b) Una segunda aparente excepción viene constituida por las donaciones entre vivos o irrevocables celebradas entre una persona que debe legítimas o mejoras, como donante, sobre algún elemento singular suyo, y el futuro beneficiario de aquellas asignaciones forzosas, como donatario, si la donación se hace precisamente a título de una u otra, lo cual, como es sabido, resulta posible en la legislación chilena. ${ }^{6}$ Añadimos el caso de las donaciones singulares no hechas a título de legítima o mejora, pero a favor de personas que a la sazón tenían la calidad de legitimarios del donante (artículo 1198 inciso $1^{\circ}$ CC.).

La aparente excepción radica en que el donatario adquiere el dominio entre vivos y no por causa de muerte; pero al suceder después al donante, el monto de lo donado a título de legítima o de mejora debe ser computado para el cálculo del primer acervo llamado imaginario (artículo 1185 CC.) e imputado después para el cálculo y pago de la legítima o mejora que deban corresponder a ese donatario en la sucesión del que fue su donante (artículos 1198 y 1206 CC.); o sólo imputado si la donación no fue a título de legítima o mejora (artículos 1198 y 1206 CC.). En tales circunstancias, aparece como que el legitimario o mejorero recibió entre vivos, merced a la donación irrevocable, el todo o una parte de su legítima o mejora en especies; lo cual vendría a equivaler como a un legado, pero justamente entre vivos (y, lo que es más grave, implicaría una convención sobre sucesión futura, como salvedad a la general prohibición establecida en los artículos 1463 y 1204 inciso $2^{\circ}$ CC.).

entrega entre vivos de lo donado? Tal entrega supone una convención entre el donante y el donatario, de oferta y aceptación de la entrega. Se podría pretender, por consiguiente, que el donatario-legatario acepta el legado anticipado al aceptar recibir la cosa, de modo que no necesitaría aceptar después de muerto el donante-testador, ni podría repudiar (artículo 1234 CC.). Lo cual puede decirse de otra manera: que el legado anticipado en que consiste la donación con entrega ya estaba aceptado al morir el donante. Pero ello contraría lo dispuesto por el artículo 1226 CC., que no permite aceptar una asignación sino después que se ha deferido, en el entendido que la delación de un legado sólo tiene lugar al fallecer el causante o, supuesta ésta, al cumplirse la condición que lo suspendía (artículo 956 inciso $1^{\circ}$ CC.). En tales circunstancias, no queda más que negar que la voluntad del donatario expresada al recibir las cosas donadas en vida del testador valga como aceptación adelantada del legado anticipado, y ella queda limitada a perfeccionar la entrega desencadenante del efecto legal de asumir el donatario los derechos y obligaciones de usufructuario. Al morir el donante, pues, se llamará al donatario-legatario a aceptar o repudiar libremente.

${ }^{6}$ Véanse los artículos 1185, 1198, 1200, 1201, 1206 CC., etcétera. El último citado expresamente habla del "donatario de especies" que es legitimario o mejorero; y es el caso que nos interesa. 
Pero no hay excepción, porque la donación entre vivos de que se trata no consiste en la actual atribución de su legítima o mejora al donatario, que son cuotas y no bienes singulares, sino precisamente en una atribución singular, con la particularidad de deber procederse después a la computación y a la imputación, o sólo a la imputación, de que antes se habló. ${ }^{7}$ Pero ambas son meramente contables. En la realidad, el donatario ya tenía adquirido el bien singular de que se trate merced a la tradición -necesariamente entre vivos- que operó en su momento, fundada en la donación irrevocable como título traslaticio de dominio (artículo 675 CC.); y no lo adquiere, en consecuencia, merced al modo llamado sucesión por causa de muerte a título singular o legado. Es sólo su valor el que después de computa o imputa. Así que no hay cómo ver en las donaciones irrevocables de que tratamos un legado convencional.

Salvada, pues, estas dificultades, se confirma que los legados sólo tienen lugar por causa de muerte.

\section{LEGADOS DISPUESTOS POR LA LEY}

1. Pero los legados no son asignaciones por causa de muerte exclusivamente testamentarias, ni, por ende, actos jurídicos, pues también es posible su disposición por la ley. La definición recoge tal realidad. ${ }^{8}$

a) La posibilidad de asignaciones por causa de muerte a título singular cuya fuente es la ley, o sea, de legados legales, aunque fue observada hace mucho tiempo, no es frecuentemente recordada por los autores, quienes por regla general emplazan el legado entre las asignaciones testamentarias. ${ }^{9}$ Por lo demás, ya el propio Código localiza el $\S 6$ : De las asignaciones a título singular en el título $4^{\circ}$ : De las asignaciones testamentarias, de su libro III. Pero el libro De la sucesión por causa de muerte del "Proyecto de 1841-1845", en el artículo 3 de su título $1^{\circ}$ decía: "La herencia y el legado se defieren por testamento o por el ministerio de la ley"; y una nota (c) añadida a esta disposición recordaba que: "Las mandas forzosas son legados que se hacen por el ministerio de la ley, aunque no las ordene el testador". ${ }^{10}$

${ }^{7}$ Si la donación es universal, sea de todos los bienes, sea de una cuota de ellos (artículo 1407 CC.), a título de legítima o mejora, o a un legitimario a la sazón pero no a tales títulos, tampoco eso es una disposición hereditaria entre vivos, porque el donante no atribuye como tal su asignación forzosa al donatario, ni universalidades o cuotas, sino los bienes singulares señalados en el inventario solemne exigido para tales donaciones; cuyo valor después es computado e imputado a la verdadera asignación por causa de muerte. Si con la donación, en cambio, se atribuyera al donante su legítima o su mejora, el acto sería nulo por contravenir la prohibición de actos sobre sucesión futura, antes recordada.

${ }^{8}$ Véase, más arriba, el capítulo II.

${ }^{9}$ Somarriva, M., Der. suc., I, núm. 358, p. 307: "No hay legados ab intestato"; Meza Barros, R., Manual, núm. 11, p. 12: "[...] como la ley no instituye legados, no existen legatarios ab intestato"; cfr. núm. 12, p. 12; Domínguez, R. \& Domínguez, R., Der. suc., II, núm. 748, pp. 737: "El legado tiene por única causa al testamento" y citan el artículo 952 inciso $2^{\circ}$ CC., del cual, empero, no se desprende lo anterior; Elorriaga, F., Der. suc., núm. 365, p. 310: "no existen legales ni tácitos ni legales".

${ }^{10}$ En Bello, Andrés, Obras completas de don [...], Santiago, Pedro G. Ramírez, 1887, XI: Proyectos de Código Civil, p. 6. 
La disposición no subsistió en el "Proyecto de 1846"; tampoco las mandas forzosas del antiguo Derecho. Pero ni lo uno ni lo otro significan que hayan desaparecido los legados dispuestos por la ley.

Claro Solar llamó la atención sobre el hecho de que la clasificación de las asignaciones en aquellas a título universal y a título singular no sólo es admitida por "las asignaciones testamentarias, que deben su origen a la voluntad personal del testador, sino también [por] las asignaciones legales que emanan de una disposición de la ley, pues la ley, a más de las asignaciones que hace para suceder en los bienes de una persona a título universal, establece asignaciones a título singular, como las asignaciones alimenticias forzosas y la porción conyugal que únicamente dan derecho a determinada cuantía de bienes y no a la universalidad que constituye el patrimonio". ${ }^{11}$

La posibilidad teórica de que la ley disponga legados no tiene nada de incongruente. De acuerdo con el artículo 953 inciso $1^{\circ}$ CC., las asignaciones por causa de muerte las hacen, bien la ley, bien el testamento; y el inciso $2^{\circ}$ del mismo artículo recalca que la simple palabra "asignaciones" significa en el libro III las hechas por causa de muerte: "ya las haga el hombre o la ley". Ahora bien, nada hay que impida a esta dualidad su combinación con la otra dualidad establecida por el Código, de asignaciones a título universal y a título singular; de guisa que cada una de ellas puede ser hecha indistintamente por el testamento o por la ley. Y como asignación a título singular es lo mismo que legado, y no existe un tercer género de asignaciones por causa de muerte que no sean aquellas a título universal o a título singular, se sigue que puede haber legados testamentarios -la regla general, por lo demás- y legales o formulados por la ley. Claro Solar ofrece los ejemplos de las asignaciones alimenticias forzosas, de que trata el $\S 1$ del título $5^{\circ}$ del libro III CC. y de la porción conyugal, hoy derogado, pero que vale como ejemplo histórico. A este último ejemplo nada hay que objetar; pero sí al primero.

b) Nosotros opinamos como aquellos que en número mayoritario sostienen ser necesaria una declaración de la obligación de pagar alimentos, establecida en vida del alimentante, por sentencia judicial firme o por transacción judicialmente aprobada, ${ }^{12}$ para que ellos constituyan asignación forzosa, a cargo de la masa hereditaria. ${ }^{13}$ De esta manera, si no había sido establecida tal obligación en vida del testador, la persona que

${ }^{11}$ Claro Solar, L., Explicaciones, XV, 3, núm. 981, p. 5. Más modernamente, sostiene lo mismo Rodríguez, P., Inst. Der. suc., I, p. 195: "Los legados, por regla general, son asignaciones testamentarias [...]. Sin embargo, a juicio nuestro, existen legados instituidos en la ley [...]", y cita el ejemplo de los alimentos que se deben por ley a ciertas personas. Más adelante, ibíd., pp. 297-298, ofrece una serie de razones destinadas a demostrar el carácter legatario de tales alimentos, sobre la base de éstos a título singular; lo cual es innegable; pero el autor no problematiza la naturaleza de asignación que a la de alimentos forzosos atribuye el Código, como haremos nosotros de inmediato, aquí mismo, letra b).

${ }^{12}$ Puede ocurrir que el supuesto alimentario haya demandado al supuesto alimentante en vida y que la sentencia se emita después de su muerte. Como los alimentos se deben desde la primera demanda (artículo 331 CC.), una vez emitida la sentencia definitiva, la obligación de pagar los alimentos se retrotrae a la fecha de la demanda y el caso opera igual que si la sentencia se hubiera emitido en vida del testador.

13 Coincidentes, al menos, en que los alimentos que constituyen la asignación forzosa son los establecidos en vida del causante, por sentencia judicial o transacción: Claro Solar, Explicaciones, XV, 1, núm. 182, pp. 166-167; Somarriva, Der. suc., II, núm. 439, pp. 363-365; Domínguez, \& Domínguez, 
cree haber tenido título para pedir alimentos al fallecido, cuando estaba vivo, ya no puede reclamarlos al heredero; lo cual significa que la obligación de pagar alimentos no declarada previamente, como se ha dicho, es intransmisible; o, lo que es igual, que el derecho a pedirlos, cuando no fue previamente declarado en vida del supuesto alimentante, se extingue con la muerte de éste. ${ }^{14}$

De lo anterior se colige, empero, que los alimentos forzosos declarados en vida del alimentante son, en realidad, deudas que éste empezó a tener en vida y se transmiten a su muerte, así que constituyen deudas hereditarias. ${ }^{15}$ El causante, en efecto, mientras vivía, sufrió la actualización, por sentencia o transacción, de su obligación legal de prestar alimentos y empezó a deberlos. Ahora bien, esa deuda no se extingue con su muerte, como es la regla general en materia de obligaciones; vale decir, es transmisible y pasa a los herederos, quienes sufren todos ellos ahora la continuación de su pago bajo la forma de una baja general (artículo 959 No 4 CC.). La obligación que el alimentante satisfacía en vida no padece una transmutación con su muerte, y se mantiene, pues, en su ser de obligación; y al respecto no hay diferencia con cualquier otra contraída por el causante en vida, a que sus herederos continúan sujetos después de muerto el que las contrajo. De acuerdo con ello, no existe una asignación forzosa de alimentos, ni, por ende, un legado legal de tales. ${ }^{16}$ Lo cual, por supuesto, no impide que el testador, en reconocimiento de su deuda de alimentos declarada en vida, no pueda disponer un legado testamentario de tales alimentos. Acerca de él trataremos más adelante. ${ }^{17}$

2. En todo caso, la anterior conclusión sobre los alimentos no excluye que sí existan verdaderos legados dispuestos por la ley. ${ }^{18}$

En tal sentido interpretamos, en efecto, la figura establecida por el artículo 1106 CC.: "Podrá ordenar el testador que se adquiera una especie ajena para darla a alguna persona o para emplearla en algún objeto de beneficencia; y si el asignatario a quien se impone esta obligación no pudiere cumplirla porque el dueño de la especie rebúsa enajenarla o pide por ella un precio excesivo, el dicho asignatario será sólo obligado a dar en dinero el justo precio de la especie./ Y si la especie ajena

Der. suc., II, núms. 891-891,1, pp. 903-910; Rodríguez, P. Inst. Der. suc., I, p. 290; Elorriaga, Der. suc., núm. 454, pp. 382-384. No se pronuncia Meza Barros (2007), núm. 407, p. 101.

${ }^{14}$ Amplia discusión en Domínguez, R. \& Domínguez, R., Der. suc., II, núms. 891-891,1, pp. 903910.

${ }^{15}$ Si hay declarados alimentos forzosos en vida del alimentario y al morir éste debía el pago de algunos períodos de ellos, nadie duda que se trata de deudas hereditarias; véase al respecto: Domínguez, R. \& Domínguez, R., Der. suc., II, núms. 891-891,1, pp. 903-904. Pero puede dudarse que se deduzcan y paguen como baja general del $\mathrm{N}^{\circ} 2$ del artículo 959, y no según su $\mathrm{N}^{\circ} 4$.

16 Sobre la naturaleza de deudas hereditarias que ofrecen los alimentos forzosos hemos tratado en un trabajo especial que, bajo el título de El carácter de deuda hereditaria de la llamada asignación forzosa de alimentos debidos por ley a ciertas personas, se publicará en la Revista Chilena de Derecho. Ahí ofrecemos la argumentación completa que respalda las afirmaciones formuladas en el texto.

17 Véase, más abajo, X, 2, b).

${ }^{18}$ En contra: Rodríguez, P., Inst. Der. suc., I, p. 297, a propósito de la asignación de alimentos forzosos, que es a título singular (véase la nota 11), dice ser también: "la única asignación de este carácter impuesta en la ley". 
legada hubiere sido antes adquirida por el legatario o para el objeto de beneficencia, no se deberá su precio, sino en cuanto la adquisición bubiere sido a título oneroso y a precio equitativo".

La disposición del testador, en orden a que se adquiera una especie ajena para darla a cierta persona o para emplearla en algún objeto de beneficencia es un legado que inicialmente impone una obligación de hacer, consistente precisamente en adquirir la especie, y sucesivamente otra, bien de dar, consistente en transferirla al destinatario final del legado; bien de hacer asimismo, como es la de emplearla en el objeto de beneficencia de que se trate. Puede, sin embargo, acaecer que el asignatario encargado de cumplir este legado no pudiere ejecutarlo debido a que el dueño de la especie se niega a enajenarla o pide un precio excesivo por ella; o a que la especie ordenada adquirir haya sido antes adquirida por el legatario o para el objeto de beneficencia, en ambos casos, a título oneroso y a precio equitativo. En tales hipótesis, la ley ordena dar dinero al legatario, o emplear dinero en el objeto de beneficencia, tanto cuanto sea el del justo precio de la especie que no fue posible adquirir.

La primitiva orden del testador es, pues, un legado testamentario normal, de efectos obligacionales. Pero cuando interviene la ley, en los casos de dificultad o imposibilidad de cumplimiento del legado original, para disponer que en sustitución se dé dinero al legatario o se emplee dinero en el objeto de beneficencia, eso, como decimos, lo debemos interpretar como la superposición de un legado legal. El testador no había ordenado, en efecto, dar o emplear dinero, sino, primariamente, un hacer consistente en adquirir cierta especie, y secundariamente, un dar o emplear la especie misma. La orden de dar una cantidad determinable de dinero al legatario o de aplicarlo al objeto de beneficencia la fulmina, pues, la ley. Y como no hay modo de excluir que ello sea una asignación por causa de muerte a título singular o legado, he ahí, por ende, un caso de legado legal.

Otro tanto acaece en la figura descrita por el artículo 1107 CC.: "El legado de especie que no es del testador, o del asignatario a quien se impone la obligación de darla, es nulo; a menos que en el testamento aparezca que el testador sabía que la cosa no era suya o del dicho asignatario; o a menos de legarse la cosa ajena a un descendiente o ascendiente del testador o a su cónyuge; pues en estos casos se procederá como en el del inciso $1^{\circ}$ del artículo precedente". El testador legó una especie ajena a él o al asignatario a quien impuso la obligación de darla, y a sabiendas de serlo; o bien, aunque no lo hubiera sabido, la legó a un descendiente o ascendiente suyo o de su cónyuge. Un tal legado no puede ejecutarse, pero no es nulo, como en el caso general de legados de cosa ajena. Nuevamente interviene la ley y dispone que se dé al legatario el justo precio de la especie ajena a él originalmente legada, que es lo señalado por el inciso $1^{\circ}$ del artículo 1107 , citado por la norma. Ahora bien, el testador no había legado dinero, sino una especie. La orden de dar una cantidad determinable de dinero viene de la ley; y como no podemos dejar de interpretar que tal es una asignación por causa de muerte y a título singular, he ahí otro caso de legado legal.

La misma caracterización exige la figura del artículo 1111 segunda parte, en relación con el 1107 CC..: "Si al legar una especie se designa el lugar en que está guardada y no se encuentra alli, pero se encuentra en otra parte, se deberá la especie; si no se encuentra en parte alguna, se deberá una especie de mediana calidad del mismo género, pero sólo a las personas designadas en el artículo 1107”. El legado asignado por el testador tiene como objeto una especie, 
para la cual indicó aquél un lugar de hallazgo; y por beneficiario a un descendiente o ascendiente suyo o de su cónyuge. Si la especie no se encuentra en el lugar designado por el testador ni en otro ninguno, la ley ordena dar una especie de mediana calidad del mismo género al beneficiario. En este evento, un legado de especie es convertido en un legado de género, para construir el cual se toma como base la especie original, en función de encontrar el género al cual pertenece y escoger dentro de él una especie concreta de mediana calidad con que pagar; pero la conversión la hace la ley y es ella la que dispone el pago con otra especie de mediana calidad del mismo género del de la original; así que se trata de un legado distinto, pero dispuesto por la ley.

En esta forma, damos por verdadero que hay asignaciones a título singular establecidas por la ley, aunque ello sea, como se ha visto, más bien excepcional. Es en mérito de ello que en la definición se recoge expresamente su mención.

\section{INEXISTENCIA DE LEGADOS CONVENCIONALES}

La hipótesis de un legado dispuesto por convención a causa de muerte ${ }^{19}$ no es posible en Chile, atendida la general prohibición de los pactos sobre sucesión futura fulminada por los artículos 1463 y 1204 inciso $2^{\circ}$ CC. En la definición, esta realidad se desprende de la función que se asigna al testamento -el ejemplo clásico de un acto unilateral- como obra de un autor y no de partes. ${ }^{20}$

a) Evidentemente, no hace excepción a ella el pacto descrito por el artículo 1204 inciso $1^{\circ}$ CC.: "Si el difunto bubiere prometido por escritura pública entre vivos a su cónyuge o a alguno de sus descendientes o ascendientes, que a la sazón era legitimario, no donar, ni asignar por testamento parte alguna de la cuarta de mejoras, y después contraviniere a su promesa, el favorecido

${ }^{19}$ El problema de saber si existen legados convencionales, que empezamos a tratar, es muy distinto a aquel de saber si existen legados entre vivos, tratado antes. Dejando mentalmente aparte la real inexistencia de ambos, podría ser que hubiera un legado entre vivos no convencional, un legado entre vivos convencional, un legado entre vivos unilateral y un legado entre vivos bilateral. Ambos supuestos, pues, se combinan. Examinaremos ahora la posibilidad de legados mortis causa pero convencionales. El hecho de que eventualmente haya legados convencionales no los privaría de su carácter mortis causa, porque este carácter, como es sabido, no proviene de que el acto tenga lugar entre dos personas vivas - de hecho, el testamento, acto mortis causa por excelencia, lo otorga un vivo- sino con la supeditación necesariamente estructural de los efectos del acto a la muerte de su otorgante o de una de sus partes. Añadimos "estructural", porque la supeditación accidental de un acto, o de sus efectos, a la muerte, no le da carácter mortis causa, como si en una compraventa se pacta que ella habrá de tener efecto al morir el vendedor. No hay que confundir, pues, los actos mortis causa y los actos referidos a la muerte: para después de mi o tu muerte (post mortem meam/ tuam), para un instante antes de morir yo o tú (pridie quam moriar/ morieris) y al morir yo o tú (cum moriar/ morieris, sobre los cuales véase Guzmán Brito, Alejandro, Derecho privado romano (Santiago, Editorial Jurídica de Chile, 1996 y reediciones posteriores), II, pp. 46-48. Tampoco la muerte deducida como elemento accidental en un acto, sea que se la deduzca como día cierto e indeterminado, o plazo ("cuando muera”), sea que como día incierto e indeterminado, o condición ("si muere antes de tal fecha”), le confiere carácter mortis causa.

${ }^{20}$ Eso es suficiente sin aparecer como menester añadir expresamente la idea de la unilateralidad, cuya mención acaso alguien eche de menos. La unilateralidad de los legados legales emana de la naturaleza unilateral de la ley. 
con ésta tendrá derecho a que los asignatarios de esa cuarta le enteren lo que le habría valido el cumplimiento de la promesa, a prorrata de lo que su infracción les aprovechare". Este pacto es de no mejorar; no de mejorar, que sin más cae en la antes dicha prohibición general. En este último caso sí que hubiéramos podido hablar de legados convencionales, cuando el causante acordara con alguna de las personas indicadas en la disposición, que determinado elemento singular suyo habría de ser de esa persona, a título de mejora (artículo 1198 inciso $1^{\circ}$ segunda parte), al morir aquél. Pero, repetimos, tal pacto es nulo en Chile.

b) Tampoco hacen excepción las donaciones revocables o por causa de muerte a título singular, que son "legados anticipados" como las declara el artículo 1141 inciso $1^{\circ}$ CC., porque tal donación es, en sí misma, un acto jurídico perteneciente a la clase de los unilaterales, ${ }^{21}$ vale decir, no es convencional, no sólo cuando se otorga la donación bajo las solemnidades de los testamentos (artículos 1139 y 1000 primera parte CC.), más también cuando se acude a las solemnidades de las donaciones entre vivos o irrevocables para perfeccionarla (artículos 1137 y 1000 segunda parte). La donación por causa de muerte también es, pues, unilateral, como los verdaderos legados.

c) Del mismo modo, no son excepción las donaciones entre vivos o irrevocables celebradas sobre un elemento singular entre la persona que debe legítimas o mejoras, como donante, y el futuro beneficiario de aquellas asignaciones forzosas, como donatario, y la donación se hace precisamente a título de una u otra; ${ }^{22}$ a las cuales añadimos las donaciones singulares no hechas a título de legítima o mejora, pero a favor de personas que a la sazón tenían la calidad de legitimario del donante (artículo 1198 CC.).

Aunque toda donación entre vivos tiene estructura convencional, ${ }^{23}$ y aquellas que se hacen a título de legítima o de mejora o a un legitimario no bajo tales títulos, ciertamente siguen esa regla, no hay excepción por las mismas razones por las cuales no son considerables como legados entre vivos: con ellas no se atribuye una legítima o una mejora, que son cuotas, sino elementos singulares; y el donatario adquiere esos elementos merced a una tradición fundada en la donación como título traslaticio, no merced a un legado. Que después el valor de los elementos donados deba contablemente computarse e imputarse, o sólo imputarse, eso no convierte a la donación irrevocable en un legado convencional.

\section{El TÍtUlo SINGULAR DE LOS LEGADOS}

1. El artículo 951 inciso $3^{\circ} \mathrm{CC}$. dice sucederse a un difunto a título singular, y, por ende, haber un legado (artículo 954 CC.): "cuando se sucede en una o más especies o cuerpos ciertos, como tal caballo, tal casa; o en una o más especies indeterminadas de cierto género, como

${ }^{21}$ Claro Solar, L., Explicaciones, XV, 3, núm. 1.150, p. 123. Lo cual no significa que el donatario no haya de aceptar la donación; sólo que ello es procedente post mortem donatoris, igual que en los legados; y también, por cierto, puede repudiarla: véase la nota 5.

22 Véase a propósito de la nota 6.

23 Véase Guzmán Brito, A. De las donaciones entre vivos, LexisNexis, Santiago de Chile, 2005, § 7 , pp. 31-34. 
un caballo, tres vacas, seiscientos pesos fuertes, cuarenta fanegas de trigo". El artículo 1066 CC. insiste en la misma idea, aunque desde otro punto de vista, en términos abstractos y con algunos complementos, pero sin usar las expresiones "asignación a título singular" ni "legado", cuando ordena que toda asignación deba ser, bien a título universal, bien "de especies determinadas o que por las indicaciones del testamento puedan claramente determinarse, o de géneros y cantidades que igualmente lo sean o puedan serlo"; porque de esta manera alude precisamente a los legados. Así que es claro el criterio legislativo de entender por legado a la asignación por causa de muerte que tiene por objeto, ora una o más especies o cuerpos ciertos, determinados o determinables, ora una o más especies indeterminadas de un cierto género, siempre que el mismo y su cantidad, empero, aparezcan determinadas o sean determinables.

El requisito de la determinación o determinabilidad del objeto podemos dejarlo a un lado, porque, no bien sea esencial para la validez de la asignación, no es propio de su objeto, sino general al objeto de todos los actos jurídicos (artículo 1461 incisos $1^{\circ} \mathrm{y}$ $2^{\circ}$ CC.). De esta forma, las propiedades que, de acuerdo con la ley, su objeto trasmite al legado radican en consistir éste en una o más especies o cuerpos ciertos, como tal caballo, tal casa, o bien en una o más especies indeterminadas de cierto género, como un caballo, tres vacas, seiscientos pesos fuertes, cuarenta fanegas de trigo. Por cierto, estas propiedades deben entenderse en relación con las asignaciones a título universal, cuyo objeto es la totalidad de los bienes, derechos y obligaciones transmisibles del causante, o de una cuota de ellos (artículos 951 inciso $2^{\circ}$ CC.), y nunca especies ni cantidades de géneros. Es la singularidad del objeto del legado el que da su nombre al título de la asignación, así como es la universalidad de las instituciones hereditaria el que da el suyo al título de la misma.

2. Lo anterior parece claro, con una advertencia empero. El artículo 951 inciso $2^{\circ}$ al decir: "sus bienes, derechos y obligaciones", habla de manera copulativa y no alternativa. No dice, en efecto: "o" sus bienes, "o" sus derechos, "o" sus obligaciones; y son los tres elementos los mentados inescindiblemente. Esto es lo determinante. Si el testador asigna "todos mis predios" o "un cuarto de todos mis predios"; "todos mis créditos" o "una mitad de todos mis créditos"; o condona "todas mis deudas" o "un cuarto de todas mis deudas", aunque habló de totalidades o de cuotas, aún así resultan ser legados y no herencias sus asignaciones, porque en ninguno de esos casos el asignatario sucede "en todos sus bienes, derechos y obligaciones" al causante ni en "una cuota de ellos", vale decir, no "en una cuota de sus bienes, derechos y obligaciones", mas únicamente en todos o algunos de esos elementos. Las dichas asignaciones son, en realidad, legados, bien de género, bien de especie. ${ }^{24}$

${ }^{24}$ El legado de "todos mis predios" no es de género, porque, si bien se designó un género ("predios"), éste es limitado ("mis" predios) y el legado lo agota ("todos"); y es como si el testador hubiera individualizado cada predio para legarlo uno a uno; así que es de especie. El legado de "un cuarto de todos mis predios”, así expresado, ofrece este problema previo de interpretación: si lo legado son tantos predios singulares cuantos, sumados, hagan un cuarto del total de predios del testador, de forma que si éste tenía dieciséis predios, los 
El precedente análisis hace ver que la diferencia entre la herencia y el legado primariamente consiste en que mientras aquélla recae sobre "bienes, derechos y obligaciones" considerados como conjunto de elementos, cuyos componentes no se singularizan, individualizan o particularizan, y que se cuantifica por la totalidad o por cuotas de ese conjunto, los legados inciden, en cambio, sobre elementos singulares, individuales o particulares del mismo conjunto, designados por su especie, en el todo o en parte o cuota, ${ }^{25}$ o por su género cuantificado según número, peso o medida o bien según totalidades o cuotas. ${ }^{26}$

3. La claridad del casi obsesivo designio legislativo, en orden a distinguir el legado de la herencia, no deja observar las consecuencias de que la tipificación de los posibles objetos de un legado, o sea, la especie y el género, se haga con respecto a las cosas corporales, que son los objetos últimos y materiales de un legado. Supóngase que un testador declara: "Condono a Ticio cinco de las diez deudas que tiene conmigo, a su elección” (argum. ex artículo 1130 CC.). Se pregunta si tal legado es de especie o de género, en los términos de los artículos 951 inciso $3^{\circ}$ y 1066 CC. El legado recae sobre deudas. Ahora bien, las deudas pueden recaer, a su vez, sobre cosas corporales específicas o genéricas, pero asimismo sobre hechos, los cuales también admiten ser designados específica ${ }^{27}$ o genéricamente. ${ }^{28}$ Por otra parte, el legado en examen no menciona cosas ni hechos, sino sólo deudas. Las deudas en sí mismas, no en cuanto a su prestación, también pueden ser designadas específicamente (la deuda de dar 1.000, contraída en tal fecha, etcétera) o genéricamente (como en el ejemplo del legado de condonación en examen).

El análisis antecedente muestra la insuficiencia de la dicción legal del artículo 951 inciso $3^{\circ}$ CC.: "una o más especies o cuerpos ciertos, como tal caballo, tal casa" y "una o más especies indeterminadas de cierto género, como un caballo, tres vacas, seiscientos pesos fuertes,

legados son cuatro de ellos en propiedad singular; o si lo legado es cada cuarto pro indiviso de cada predio, de modo que, en el mismo ejemplo, el legatario tendrá un cuarto pro indiviso en cada uno de los dieciséis predios, en cada caso en comunidad con los herederos. Por supuesto, el problema es de hecho y cabe resolverlo de acuerdo con las reglas generales de interpretación de los testamentos. Aquí, pues nos limitamos a decir lo que sigue: bajo la primera interpretación, el legado es de género y equivale a que el testador hubiera dispuesto: "lego cuatro de mis dieciséis (o de todos mis) predios"; en tal caso, debe aplicarse el artículo 1114 CC. y el deudor (el heredero gravado, o todos los herederos o algunos de éstos) es el que elige los predios específicos con que cumplir el legado, como en todas las obligaciones de género; bajo la segunda interpretación, el legado es de especie, en donde la especie legada es un cuarto de cada uno de los predios del testador; o, si se quiere, cada uno de los predios del testador, en un cuarto. Con estos mismos criterios, mutatis mutandis, deben resolverse los demás ejemplos de créditos y deudas legados.

25 Se puede legar "el fundo Corneliano" o "un tercio del fundo Corneliano".

${ }^{26}$ Se puede legar, como se vio, la totalidad de un género limitado ("todos mis predios") o una cuota de él ("un cuarto de mis predios").

${ }^{27}$ En el contrato de arrendamiento de los servicios inmateriales de una orquesta, la especificación puede consistir, por ejemplo, en interpretar tales y cuales piezas, designadas por su autor y nombre.

${ }^{28}$ Como, en el mismo ejemplo anterior, cuando se trata de interpretar cualesquiera dos sinfonías de Mozart. 
cuarenta fanegas de trigo", porque está referida sólo a cosas corporales. Menos reprochable es la literalidad del artículo 1066 CC.: "especies determinadas" y "géneros y cantidades", por más que la referencia mental de esta disposición sea también a cosas corporales, porque el hecho es que bajo tales dicciones caben, no sólo las cosas, mas también los hechos y las cosas incorporales, como las deudas de nuestro ejemplo.

En tales circunstancias, la definición del título singular -que en sí mismo no está en duda con respecto a los legados- no debe adherirse estrictamente a la letra del artículo 951 inciso $3^{\circ} \mathrm{CC}$. y ha de obtener partido de la mayor amplitud que permite la dicción del artículo 1066 CC. No se trata de que el legado deba necesariamente tener por objeto especies o cuerpos ciertos corporales o especies corporales indeterminadas de cierto género, sino de que haya de recaer sobre cosas corporales, incorporales o hechos designados, ora específica ora genéricamente.

Nos ha parecido suficiente expresar este rasgo de los legados, esencial frente a la herencia, mediante la mención de la expresión técnica "a título singular" en su definición, entendida, empero, como se ha dicho precedentemente.

\section{LA ATRIBUCIÓN Y LA EXTINCIÓN DE DERECHOS REALES Y PERSONALES COMO EFECTO DE LOS LEGADOS}

1. De la doble manera de designar los elementos particulares sobre que necesariamente deben recaer los legados -específica o genéricamente- en los artículos 951 inciso $3^{\circ} \mathrm{y}$ 1066 CC. viene, tanto la summa divisio de aquéllos fijada por la doctrina, en legados de especie y legados de género, como la definición que suele darse de los legados con base en ella, ${ }^{29}$ lo mismo que la caracterización de cada tipo con ciertas notas diferenciadoras, principalmente reducidas al efecto real del legado de especie y meramente obligacional de aquel de géneros. ${ }^{30}$ En otro lugar hemos formulado una crítica a se-

${ }^{29}$ Claro Solar, L., Explicaciones, XV, 3, núm. 984, p. 10, aunque no ofrece una formal definición del legado, insiste en lo que expresa en varios lugares en orden a que: “[...] asignación a título singular [es] aquella en que se sucede al difunto en determinados bienes o cuerpos ciertos [...] o en una o más especies indeterminadas de determinado género [...]”; Somarriva, M., Der. suc., I, núm. 357, p. 307, bajo la rúbrica de "Concepto" de las asignaciones a título singular, se limita a repetir la letra del artículo 951 inciso $3^{\circ}$ CC.; Meza Barros, R., Manual, no ofrece una definición del legado, pero, en función de diferenciarlo de la herencia, es cierto que dice en el núm. 10, p. 12: "[...] el legado se refiere únicamente a cuerpos ciertos o cosas determinadas genéricamente"; Rodríguez, P., Inst. Der. suc., I, p. 194: "el legado [...] es una asignación mediante la cual el testador transmite a una persona el dominio de una especie o cuerpo cierto o el derecho a exigir la tradición de una o más especies indeterminadas de cierto género, ya sea a la sucesión, a uno o más herederos o a uno o más legatarios”; Elorriaga, F., Der. suc., núm. 364, p. 309: "[...] los legatarios o asignatarios a título singular son aquellos que suceden al causante en una o más especies o cuerpos ciertos [...]; o en una o más especies indeterminadas de cierto género [...]”; si bien más adelante, ibíd. pp. 309310, reconoce la dificultad de dar una noción exacta de legado, atendido que varias figuras posibles de tal no se adaptan a los conceptos antes emitidos. Domínguez, R. \& Domínguez, R., Der. suc., II, núm. 745, pp. 735-736, renuncian a definir el legado.

30 Claro Solar, L., Explicaciones, XV, 3, núm. 1045, p. 61; Somarriva, M., Der. suc., I, núm. 363, pp. 286-287; Meza Barros, R., Manual, núm. 347, p. 87 y núm. 355, p. 89; Domínguez, R. \& Domínguez, 
mejante caracterización, sobre la base de mostrar el análisis que no necesariamente los legados de especie producen efecto real, pues en variadas situaciones la especie puede ser objeto de un legado de efectos obligacionales; y que la dualidad efecto real-efecto obligacional no agota la tipología de efectos de los legados, porque a ella es menester añadir el efecto extintivo de derechos reales y el efecto extintivo de derechos personales (legados liberatorios), sin perjuicio de que, en muchos casos, un legado de efecto real o de efecto obligacional pueda reflejamente cumplir también la función liberatoria de derechos reales y personales. ${ }^{31}$ En el mencionado trabajo insistimos, además, en que la verdadera función del artículo 951 inciso $3^{\circ} \mathrm{CC}$. al definir el legado por su objeto, bien una especie, bien un género, no es para atribuir a cada tipo así definido el efecto real u obligacional, respectivamente, sino para diferenciar al legado de la herencia, desde el punto de vista del objeto universal de ésta y singular de aquél. ${ }^{32}$ En este sentido, la singularidad del objeto es propia de los legados, no ciertamente frente a los demás actos jurídicos, pues hay muchos de ellos que también pueden o deben recaer sobre elementos singulares, sino frente a las herencias, que nunca pueden recaer sobre tales elementos,

Estas conclusiones tienen incidencia en nuestro actual tema. En la definición del legado, es necesario mencionar el título singular que los caracteriza, porque así se mantiene el criterio legal de su distinción con la herencia, aunque no desarrollar su consistencia, y es tal lo que se refleja en nuestra definición, como hemos aclarado en el capítulo anterior. Pero, al mismo tiempo, la definición no debe circunscribirse a dar por único efecto de los legados a la adquisición del dominio sobre una especie o de un crédito sobre algún género, porque con ello no se agota la rica tipología de efectos producida por los legados.

2. No nos detendremos en el detalle de aquélla y nos limitaremos a enumerarla. Fundados en anteriores investigaciones nuestras, hemos de recordar que un legado puede ser:

a) de efecto real; y se entiende por tal aquel que atribuye inmediatamente al legatario: i) el dominio de una cosa corporal del testador; o ii) la titularidad de un preconstituido derecho real transmisible suyo; o iii) la titularidad de un tal derecho, pero constituido por el legado mismo en cosa del testador; o iv) la titularidad de un crédito preexistente de éste; de modo de hacerse el legatario dueño de la cosa, o titular del derecho real legados y, en ambos casos, disponer de la pertinente acción real; o bien de hacerse titular del crédito legado, y disponer ahora de la correspondiente acción personal para exigirlo; ${ }^{33}$

R., Der. suc., II, núm. 795, p. 784; Rodríguez, P., Inst. Der. suc., I, pp. 199-200; Elorriaga, F., Der. suc., núm. 370, p. 314.

31 Véase Guzmán Brito, A. "La tipología de los legados en el Derecho civil chileno”, en Revista de Derecho de la Pontificia Universidad Católica de Valparaíso 27, Valparaíso, 2006, Semestre I, pp. 51-85.

32 Ibid., pp. 54-55.

33 Sobre el legado de efecto real: Guzmán Brito, A., La tipología de los legados, cit. (n. 31), pp. 57-62. 
b) de efecto obligacional, que es aquel generador de una obligación nueva de dar, hacer o no hacer, a cargo de uno, varios o todos los herederos instituidos por el testador (o de un legatario) y, correlativamente, un crédito en favor del legatario contra el o los asignatarios gravados, frente a los cuales dispone de una acción personal de cumplimiento, llamada acción del testamento (actio ex testamento); ${ }^{34}$

c) de efecto liberatorio de deudas del legatario para con el testador, consistente en la simple condonación, liberación o remisión que de la obligación de cierto deudor suyo el testador pronuncia en el testamento; ${ }^{35} \mathrm{y}$

d) de efecto extintivo de derechos reales transmisibles y renunciables del testador, consistente en la declaración de éste, en orden a renunciar o abdicar cierto derecho de la clase dicha, de que es titular, el cual, en consecuencia, no se trasmite contra sus propios herederos. ${ }^{36}$

Estos cuatro tipos posibles de legados quedan generalizados bajo la expresión “atribución o extinción [...] de un derecho real o personal" usada en nuestra definición, porque un legado del tipo a) atribuye derechos reales y también personales; uno del tipo b) atribuye derechos personales; el del tipo c), al liberar de deudas, extingue derechos personales del testador; y el del tipo d) extingue derechos reales suyos; así que la fórmula empleada cubre a todos los tipos.

\section{Problematización de LA idea del Legado COMO SUCESión POR CAUSA DE MUERTE A TÍTULO SINGULAR}

En el Código Civil, "legado" es otro nombre para "asignación por causa de muerte a título singular" (artículos 953 inciso $1^{\circ}$ y 954 CC.); y el legado es la manera de hacer operativa la sucesión a título singular de una persona difunta (artículo 951 incisos $1^{\circ}$ y $3^{\circ}$ ). En consecuencia, un legatario o asignatario de legado o asignatario por causa de muerte a título singular aparece como un sucesor del difunto; y es esto lo que nos interesa examinar ahora.

Nadie ha dudado que en la herencia exista verdaderamente una sucesión por causa de muerte: el heredero representa a la persona del difunto (artículo 1097 CC.). En esta dicción, "representar" no mienta el fenómeno designado con el mismo término (o con el sustantivo derivado) cuando se lo emplea entre vivos, y que está definido por el artículo 1448 CC. Tampoco, por cierto, alude a la representación en la sucesión intestada (artículo 984 CC.). El vocablo, en realidad, es usado en el sentido de "sustituir" al difunto. De esta sustitución deriva la adquisición por el heredero del dominio de las cosas corporales, de los derechos reales, de los créditos y de las obligaciones, copulativamente y en cuanto transmisibles, que hasta el instante de morir estaban en cabeza del ahora difunto.

\footnotetext{
${ }^{34}$ Sobre estos legados: ibíd., pp. 62-71.

35 Acerca de la materia: ibid., pp. 71-72.

${ }^{36}$ En lo concerniente a tales legados: ibid., pp. 72-75.
} 
Ahora bien, un legatario no representa al difunto (artículo 1104 inciso $1^{\circ} \mathrm{CC}$.); es decir, no lo sustituye. Tan sólo, pues, adquiere el específico elemento legado. En consecuencia, no puede decirse que "suceda" al difunto, por ejemplo, en el dominio del fundo que recibió, salvo que se emplee el término en el vago y no técnico sentido de "venir después de", que es el mismo en que lo usamos cuando decimos, por ejemplo, en un debate, que tal persona sucedió en el uso de la palabra a otra. En ese mismo sentido se lo podría emplear entre vivos, cuando se dijera que el comprador "sucedió" al vendedor en el dominio de la cosa comprada. Así que, en sentido técnico, una sucesión por causa de muerte a título singular es un contrasentido, tanto como entre vivos.

Por lo demás, en muchos casos ni siquiera puede operar el concepto vulgar y atécnico de sucesión. En los legados de género, por ejemplo, no hay como ver ni siquiera una sucesión en aquel sentido. El testador lega 1.000 a Ticio y grava a otro legatario con el pago de ese legado. El legatario gravado podría cumplir el legado con dinero de su propio patrimonio. Pero aun cuando lo hubiera cumplido con dinero que recibió de los herederos para satisfacerle su propio legado (los cuales herederos, a su vez, pudieron no extraer de la herencia ese dinero sino, de nuevo, de su patrimonio particular). ¿En qué punto hay ahí una sucesión, no diremos en sentido técnico, más siquiera en sentido vulgar? El legatario lo único que derivó del testador fue un crédito establecido en su favor merced al legado. Ese crédito empezó a existir al morir el testador y nunca fue suyo. Así que, ¿cómo decir que el legatario sucedió al difunto en ese crédito? Y en cuanto al dinero, menos aún puede hablarse de sucesión, pues el dinero, como fungible que es, pudo venir de cualquier fuente y no del patrimonio del causante. El análisis de muchas otras formas de legado permite obtener consecuencias semejantes. Por ejemplo, en los legados condonatorios, en virtud de los cuales el testador remite cierta deuda que alguien tenía para con él: la consecuencia es que la deuda resulta extinguida. ¿En qué ha sucedido el legatario al difunto, incluso en sentido atécnico? No en el crédito que este tenía, pues se extinguió. No en el objeto debido, que si era un infungible, pertenece al deudor o, eventualmente, a un tercero; y si era un fungible, representa sólo un valor, pero nada material, ni siquiera unas monedas o billetes concretos, que no pueden ser en sí mismos mirados como debidos. O bien el testador constituyó por legado un usufructo a favor de alguien: aunque el legatario derivó su usufructo del testador, no puede decirse que lo haya sucedido en él, porque mientras vivía el testador, ese usufructo no existía y cuando empezó éste a existir, aquél ya está muerto. Nuevamente debe reconocerse que no hay manera de ver ahí una sucesión, ni aún en sentido vulgar.

Es cierto que todo legado normalmente implica un detraimiento patrimonial a la masa hereditaria. La especie legada viene de ahí y, de no haber sido legada, haría parte de la herencia; la deuda condonada, de no haberlo sido, hubiera hecho parte de la hijuela de deudas hereditarias; la servidumbre extinguida por cierto legado, hubiera permanecido en el patrimonio, en cuanto adherida al fundo dominante hereditario, etcétera. Pero eso no autoriza a ver una sucesión en cada legado. Sin contar con que puede darse el caso de un legado que no grave a la masa hereditaria sino a un asignatario, como en los legados de especie perteneciente a aquel a quien se impone la obligación de darlo (artículo 1107 primera parte, a contrario). 
No es el momento de fijarnos en el origen del deplorable dogma de la sucesión por causa de muerte a título singular. ${ }^{37}$ Sólo tenemos que lamentar que el Código lo tenga acogido, por más que, llamado a rendir cuentas de él, no pueda defenderlo con éxito. La doctrina chilena, con todo, lo ha recibido sin más; ${ }^{38}$ aunque algunos autores no han dejado de observar su inconsistencia. ${ }^{39}$

Ahora bien, el concepto de sucesión por causa de muerte a título singular no tiene por qué ingresar en la definición del legado. No se trata de ignorar un concepto que, no bien erróneo, es legal, sino de instalarlo en su justo lugar de género lejano, en circunstancias que una buena definición exige un género próximo; así que se puede omitir al más lejano en nuestra definición.

\section{GRATUIDAD}

Procede ahora el estudio de tres rasgos que en la definición van asociados a los efectos atributivo y extintivo, como son su gratuidad, liberalidad y lucratividad.

1. Comencemos, pues, con la gratuidad. En general, acto gratuito es aquel que atribuye algo a alguien, sin contraprestación en general ni precio en especial, de parte del que recibe la atribución. De lo contrario es oneroso. El artículo 1440 CC. conoce la distinción, pero aplicada al contrato, que es gratuito o de beneficencia: "cuando sólo tiene por objeto la utilidad de una de las partes, sufriendo la otra el gravamen"; y oneroso: "cuando tiene por objeto la utilidad de ambos contratantes, gravándose cada uno a beneficio del otro". Como los legados son actos unilaterales, en los cuales no hay partes sino sólo un autor, los conceptos del Código sobre la materia no les son en principio aplicables. Pero se mantiene en pie a su respecto el concepto inicialmente ofrecido.

Preliminarmente digamos que para la perfección del legado en vida del causante, el legatario, por supuesto, no debe ni necesita operar ninguna prestación, en general, ni pagar un precio, en especial, ni obligarse a lo uno o lo otro, a cambio de la atribución en su favor, contenida en el legado perfeccionado o por perfeccionar. Nada de eso está previsto en la ley ni podría estarlo sin contradecir la general prohibición de pactos sobre

${ }^{37}$ Si se nos pregunta con qué reemplazarlo, respondo que con diversas figuras: los legados simples y normales del dominio de especies son un modo de adquirir autónomo y de constituir derechos reales; los legados de especie con efectos obligacionales y de género (con los mismos efectos) son una fuente de obligación unidos a su aceptación (y, por lo demás, así los considera el Código cuando los mira como cuasicontratos en su artículo 1437); el legado liberatorio es un modo de extinguir obligaciones; también puede ser un modo de extinguir con respecto a los derechos reales; etcétera.

${ }^{38}$ Claro Solar, L., Explicaciones, XV, 1, núms. 5 y 12, pp. 11 y 14-15; lo propio cabe decir de Somarriva, M., Der. suc., I, núm. 14, pp. 27-28; Meza Barros, R., Manual, núm. 9, pp. 11-12; Rodríguez Grez, P., Inst. Der. suc., I, p. 16, quien incluso avanza una definición general de la sucesión por causa de muerte en las que los legados aparecen integrados.

${ }^{39}$ Domínguez, R. \& Domínguez, R., Der. suc., II, núm. 745, p. 736; pero escasamente crítico ibíd, I núm. 86,1, p. 131; Elorriaga, F., Der. suc., núm. 364, pp. 309-310. 
“sucesión” futura -para emplear la terminología legal-. Está claro, en efecto, que si el legatario resultare obligado a operar o a prometer operar contraprestaciones ya en vida del causante y a éste, eso tendría que ser merced a una convención entre ambos, y tal convención necesariamente envolvería una de las que la ley por otro lado prohíbe; sin hacer caudal de que, incluso antes que eso, los legados pasarían a ser actos de estructura bilateral.

Una vez fallecido el causante y deferido el legado, tampoco es requisito para aceptarlo o adquirirlo que el legatario deba operar u obligarse a operar contraprestaciones o pagar u obligarse a pagar precios, en beneficio de la herencia o de algún heredero.

No parece que fuere necesario abundar en el punto; de resultas de lo cual el carácter gratuito de los legados, en los términos dichos, comparece como indiscutible. ${ }^{40}$

2. Pero hay ciertas clases de legado que podrían prestarse a ser interpretadas en el sentido de portar el carácter opuesto, o sea, el de la onerosidad. En general, se trata de los legados que de una u otra manera dejan gravado a su asignatario con ciertas cargas impuestas por el testador o por la ley. Atendido que, con respecto a las asignaciones a título universal, en principio gratuitas, según doctrina común, se ha dicho verse afectadas en su gratuidad merced a las cargas que por testamento o ley deben soportar, ${ }^{41}$ alguien podría querer aplicar la misma observación a los legados, de manera de también limitarles en casos semejantes su carácter gratuito

En consecuencia, examinemos con alguna detención las diversas hipótesis discutibles en función de un diagnóstico exacto.

a) Se presenta, en primer lugar, el legado modal, vale decir, aquel legado que incluye la obligación impuesta por el testador al legatario, de aplicar el todo o parte de su emolumento a un fin especial o de sujetarse él mismo a ciertas cargas (artículo 1089 CC.). Una vez aceptado el legado, se hace operativa la atribución que él implica, ya que el modo no suspende tal operatividad (argum. ex artículo 1089 parte final CC.); pero el asignatario resulta obligado a cumplir el modo establecido, salvo que sea en su propio beneficio (artículo 1092 CC.); y si la asignación modal fue complementada expresamente con una cláusula resolutoria, el incumplimiento del modo conduce a la restitución de lo legado y sus frutos (a favor de los herederos), aunque, esta vez, el modo ceda en beneficio del legatario (artículo 1090 CC.).

Por lo que a nosotros atañe, lo juzgamos así:

i) formalmente no cabe decir que el legado modal sea oneroso, en el sentido en que lo son los actos onerosos, porque no es que el legatario deba hacer alguna (contra) prestación para adquirir el legado; de hecho, como se recordó, la presencia de un modo no suspende el efecto de la asignación que lo soporta. Por lo demás, la carga

${ }^{40}$ Conformes por lo demás: Claro Solar, L., Explicaciones, XV, 1, núm. 1, p. 9 (de paso, aunque habla de "título de adquisición lucrativa", no bien en el "Índice", p. 457, diga: "títulos de adquisición gratuitos"); Somarriva, M., Der. suc., I, núm. 13, p. 27; Meza Barros, R., Manual, núm. 2, p. 9; Rodríguez, P., Inst. Der. suc., I, pp. 19-20; Elorriaga, F., Der. suc., núm. 15, p. 24.

${ }^{41}$ Rodríguez, P., Inst. Der. suc., I, p. 19. 
modal ni siquiera puede técnicamente ser considerada como una (contra)prestación, ni con respecto, por cierto, al que dispuso la asignación, que ahora falta; ni con respecto al beneficiario del modo, que no fue parte del acto. El modo, hay que reiterarlo, no es precio del legado;

ii) materialmente o, si se quiere, económicamente, no bien resulte indiscutible que el modo resta al emolumento de la asignación, y puede incluso llegar a consumirlo todo, en ambos casos, empero, aquélla sigue siendo "gratis", vale decir, gratuita para el legatario, porque la prestación exigida por el modo, o es extraída del emolumento mismo del legado, y entonces el legatario nada expende del resto de su patrimonio -como si se dijera que de sus recursos anteriores y ajenos al legado-; ${ }^{42}$ o es extraída de dicho resto, y ahora tal expendio resulta de todos modos contrabalanceado por el intacto emolumento de la asignación y contablemente imputado a él; así que no puede decirse, bajo este respecto, que el legatario sufra un gravamen económico;

iii) pero puede acaecer que la prestación en que el modo consiste exceda al emolumento del legado, de guisa que el asignatario deba gastar, además, una parte de su patrimonio no formado por el legado, la que sea necesaria para sufragar el exceso; y en este caso sí resulta ser cierto que el legado dejó de ser gratis para el asignatario en cuanto a ese exceso, que su monto llegó a ser una gravamen para él y que, en la misma medida, el legado empezó a serle oneroso. ${ }^{43}$ Todo esto a menos que apliquemos, por analogía, el artículo 1364 CC. al legatario modal: "El legatario obligado a pagar un legado, lo será sólo hasta concurrencia del provecho que reporte de la sucesión; pero deberá hacer constar la cantidad en que el gravamen exceda al provecho". La disposición atañe el "legatario obligado a pagar un legado", esto es, al llamado sublegatario, no al "legatario obligado a cumplir un modo". Ahora bien, la única, y por ello abierta razón que funda esta norma es la salvaguardia de esta diferente configuración de la responsabilidad de los herederos y los legatarios: mientras aquellos responden ultra vires hereditatis, éstos sólo responden "intra vires legati”. Si un legatario quedase obligado a pagar la deuda testamentaria que soporta, o sea, cierto legado, más allá del provecho que reporte de la sucesión, vale decir, normalmente, más allá del valor de su propio legado, se lo haría responder como un heredero. Ahora bien, un legatario modal es, en lo principal y sustantivo, un legatario y si se lo obligase a responder por el modo más allá del provecho reportado de su propio legado, se lo estaría obligando a responder como un heredero; y francamente no descubrimos contrarrazones que justifiquen proceder así con tales legatarios. Así

42 Expresamos así la idea, porque desde que el legado opera el efecto que le es propio, su objeto -la especie asignada en dominio, el crédito sobre géneros, el derecho real constituido, el valor condonado- se incorpora en el patrimonio del legatario junto a sus demás cosas, derechos y créditos, así que aun cuando el modo sea cumplido con el emolumento del legado se lo cumple con el patrimonio del asignatario.

43 Obsérvese que si el modo consume todo el emolumento del legado, o lo excede, legado hay, porque en esta materia no está dicho que la existencia de la asignación dependa de haber aumento patrimonial para el legatario, como sí lo está en tema de donaciones, que la de éstas depende de haberlo para el donatario (ex artículo 1398 CC.). 
que opinamos que cuando el sufragio del modo excede al emolumento del legado modal, el legatario puede limitar su responsabilidad de cumplirlo, en los términos que señala el artículo 1364 CC. ${ }^{44}$ En tales condiciones, la onerosidad de un tal legado modal es sólo una opción para el legatario, cuando no desee invocar la citada disposición. Pero desde el punto de vista del ordenamiento, el legado está pensado como gratuito para él;

iv) por consiguiente, es en este último caso en que debe aceptarse haber onerosidad económica en el legado modal; lo cual no significa que desde un punto de vista técnico-jurídico sea un acto oneroso. Al revés, aunque el modo sea un gravamen desde un punto de vista técnico-jurídico, no por ello es de necesidad es un gravamen económico. El único caso en que éste se junta con el gravamen jurídico es aquél en que el modo excede al emolumento de la asignación, examinado bajo el punto iii).

b) Enseguida comparecen los legados de cierta especie perteneciente a un legatario (artículo 1107 CC.). De acuerdo con la disposición citada, el testador, que dispuso cualquier legado, puede disponer otro, en cuya virtud legue una especie perteneciente al primer legatario, el cual queda obligado a darla al asignatario de este segundo legado. El esquema de la operación es éste: el testador dispone primeramente: "Lego 100.000.000 a Ticio"; y después dispone otra vez: "Lego el fundo Corneliano de Ticio a Cayo". Si Ticio acepta su legado, queda obligado a dar el fundo Corneliano de su propiedad a Cayo, mediante tradición solvendi causa.

No hay cómo decir que la obligación de dar Ticio el fundo a Cayo sea una (contra) prestación inherente a su propio legado de dinero, o un precio de éste, siendo como es una obligación extrínseca al primer legado, pues emana de una asignación testamentaria distinta. Otra cosa es que el segundo legado disminuya el emolumento económico del primero, o lo alcance completamente; pero aún en tal caso, éste sigue siendo gratis o gratuito para el asignatario. En cuanto a que lo exceda, ahora sí que el artículo 1364 CC. recibe aplicación directa, pues la hipótesis que tratamos cae exactamente en la previsión de esa norma, consistente en un "legatario obligado a pagar un legado", el cual, pues, en defensa de la gratuidad del suyo, puede limitar el pago del legado que debe al provecho que le reporte el que se le defirió.

c) En fin, se puede presentar la hipótesis de un testador que grave con el pago de ciertos legados a los legatarios instituidos en su testamento, lo cual es posible de acuerdo con el artículo 1360 CC. El esquema de la figura se forma cuando un testador dispone: "Lego 1.000 a Ticio"; y después: "Lego 500 a Cayo e impongo a Ticio la carga de pagarle este legado". El análisis de la figura es similar al conducido en la letra precedente. La carga extrínseca de pagar el segundo legado no es un precio del primero; y aunque aquél disminuya, como en el ejemplo, o anule el emolumento de éste, en ningún caso se impide la gratuidad. En el resto, el artículo 1364 CC. es también directamente aplicable, si el segundo legado excede al emolumento del primero.

\footnotetext{
${ }^{44}$ Conformes Domínguez, R. \& Domínguez, R., Der. suc., II, núm. 857, p. 849.
} 
3. También puede ocurrir que los legatarios vean sobrevinientemente sometidos a reducción parcial o total el emolumento de sus legados, como consecuencia del ejercicio de la acción de reforma de testamento por alguno de sus legitimados (artículos 1104 inciso $2^{\circ}, 1362$ y 1363 CC.). El caso se da cuando el testador dispuso legados que terminaron por lesionar las asignaciones forzosas que debía respetar. Puesto que el efecto directo de la acción de reforma es la restauración de la integridad de la asignación forzosa lesionada, aquélla debe repercutir en los legados por cuyo exceso de había producido la lesión, los que han de sufrir una correlativa y congruente reducción a prorrata de sus montos y en subsidio de las asignaciones a título universal que habían provocado la misma lesión. Según el estado en que se encuentren los legados afectados con relación a su cumplimiento, la reducción puede hacerse operativa merced a un simple cumplimiento reducido, como cuando al legatario de 1.000, cuyo legado quedó sujeto a reducción, merced a ésta sólo se le pagan 500; o una verdadera restitución, como cuando los 1.000 del legado ya habían sido pagados y entonces procede que el legatario restituya 500 al asignatario forzoso lesionado. Pero fuere cual fuere el caso, y especialmente en el segundo, lo cierto es que la reducción del emolumento no puede ser mirada como una (contra)prestación del legatario ni un precio de su legado: la reducción y eventual restitución no son "para" conseguir el legado, sino "por" haber conseguido el legado y obedece a principios muy distintos a aquellos a los que obedece la onerosidad; así que no podemos ver comprometida la gratuidad en el caso.

4. Lo propio cabe sostener cuando se hacen procedentes reducciones de los legados, con o sin restitución para hacerlas operativas, a fin de hacer efectiva la responsabilidad subsidiaria de los legatarios por el pago de las deudas hereditarias, cuando no hay bienes suficientes en el caudal sucesorio para solventarlas (artículos 1104 inciso $2^{\circ}, 1362$ y 1363 CC.).

En este estado de cosas, no tenemos más que corroborar el carácter gratuito de los legados, sin excepciones.

\section{Liberalidad}

Comparece ahora la liberalidad.

1. El vocablo "liberalidad", que ofrece varios significados, es usado aquí en el mismo sentido en que lo hemos usado en otro lugar para definir las donaciones, vale decir, para denotar el carácter libre, en el sentido de jurídicamente no-debido, de una atribución patrimonial, porque operarla o no operarla ha dependido completamente del que la opera, sin haber mediado, pues, una previa obligación jurídica de operarla (aunque pudo haber intervenido alguna de carácter moral). ${ }^{45}$ Este rasgo de los legados, que es el mismo de las donaciones en toda su vasta tipología y de las fundaciones, por

${ }^{45}$ Guzmán Brito, A., De las donaciones entre vivos, cit. (n. 23), pp. 39-41. 
metonimia da su nombre a todo ese vasto grupo de actos que llamamos precisamente liberalidades.

La liberalidad - a diferencia del caso de las donaciones- no aparece positivamente establecida en la ley. Ella, pues, lo supone; y lo manifiesta negativamente desde que no concede ninguna acción destinada a reclamar contra los herederos cuando quiera que su causante no haya legado o haya legado de cierta manera y no de otra, o en cierto monto y no en otro, etcétera. No hay, pues, legados forzosos. Por lo demás, la general prohibición de pactos entre vivos sobre sucesión de una persona viva (arts. 1463 y 1204 inciso $2^{\circ}$ CC.), que, por cierto, incluye a los legados, también puede ser mirada, entre tantos otros aspectos bajo los cuales admite ser mirada, como un medio de proteger el carácter liberal de los legados: cualquier convención, en tanto, destinada, entre otros propósitos, a crear la obligación de asignar legados una persona a otra en su testamento es, en efecto, nula. Tampoco vale un legado captatorio (artículo 1059 CC.). Ni siquiera hay obligación de asignar legados a los legitimarios ni de distribuir bajo forma de legados la cuarta de mejoras entre quienes pueden ser favorecidos con ella. El testador que se halle en el caso de deber respetar legítimas y mejoras ya las obsequia al asignar cuotas en la dimensión debida a sus respectivos asignatarios forzosos. Puede, por cierto, si lo decide, asignarles legados a título de legítima o mejora, o simplemente legarles, y todos ellos después habrán de computarse para el cálculo del primer acervo imaginario e imputarse a la correspondiente asignación forzosa, o sólo imputarse en el último caso. Pero no está ese testador obligado a legar así y, de no haberlo hecho, no podrá reclamar el interesado por no haber aquél legado, aunque pueda reclamar si es que éste no respetó las porciones o cuotas forzosas en cuanto tales.

\section{Sin embargo, hay legados a los que podría discutirse su carácter liberal.}

a) Comparecen a examen, en primer lugar, los diversos tipos de legados de lo debido que un deudor dispone a favor de un acreedor suyo en su testamento, cuyo régimen general establece el artículo 1131 CC.: "Lo que se lega a un acreedor no se entenderá que es a cuenta de su crédito, si no se expresa, o si por las circunstancias no apareciere claramente que la intención del testador es pagar la deuda con el legadol Si asi se expresare o apareciere, se deberá reconocer la deuda en los términos que lo haya hecho el testador, o en que se justifique haberse contraído la obligación; y el acreedor podrá a su arbitrio exigir el pago en los términos a que estaba obligado el deudor o en los términos que expresa el testamento". Sobre este legado hemos tratado en otro lugar. ${ }^{46}$ En este momento, por cierto, sólo nos interesa el punto relativo a su liberalidad. Ticio debe 1.000 entre vivos a Cayo; y dispone en su testamento: "Para pagarle lo que le debo, lego 1.000 a Cayo”. Muerto el testador y aceptado que sea el legado por Cayo, puede éste reclamar 1.000, normalmente al heredero. Pagado que sea el legado, la deuda ahora hereditaria de 1.000 para con Cayo se extingue. ¿Fue liberal ese legado?

Si examinamos el asunto desde el punto concerniente a la libertad del testador para legar lo debido a su acreedor o no legárselo, debemos responder que el legado

\footnotetext{
${ }^{46}$ Véase Guzmán Brito, A. La tipología de los legados en el derecho civil chileno, cit. (n. 31), pp. 80-84.
} 
sigue siendo liberal. El testador, en efecto, aunque debía 1.000 no tuvo la obligación de legar 1.000. Cuando no lo hubiera hecho, Cayo, el acreedor hereditario, no hubiera tenido acción contra el heredero para reclamar por el defecto de legado. Por cierto, igual hubiera podido exigir el pago de su crédito al heredero; pero no con base en no haber existido el legado, sino de acuerdo con las reglas generales sobre sucesión por causa de muerte a título universal, que siempre incluye las deudas (artículo 951 inciso $2^{\circ}$ y 1354 CC.). Incluso más, aun en el evento de haberse dispuesto el legado al que nos referimos, el acreedor puede invocar la causa entre vivos original de su crédito y reclamar con la acción de ella derivada, desentendiéndose, por ende, del legado, como lo permite el artículo 1131 CC., antes transcrito.

Pero si ahora examinamos el tema desde el punto de vista del objeto del legado, no es menos cierto que él era debido y que cuando el testador libremente escogió legarlo, asignó algo precisamente debido. Por consiguiente, desde este punto de vista, el legado en examen no es liberal. Asimismo observado, en realidad esta asignación cumple la función de un pago mortis causa. Ahora bien, por definición, un pago es la prestación de lo que se debe (artículo 1568 CC.). De haber sido hecho por el testador en vida, jamás hubiera podido ser el equivalente entre vivos del legado, cual es la donación irrevocable (argum. ex artículos 1397, 2299 y 2295 CC.). ${ }^{47}$ Pero como el mundo de los legados refleja en el ámbito mortis causa casi todo lo que es posible operar entre vivos, sólo que bajo un arquetipo único: el del legado -por más que adopte una notable variedad de subtipos-, de modo que no existe paralelamente al pago entre vivos un pago mortis causa (que no sería un legado), sino sólo la función pago operada por un legado, he ahí la razón por la cual se produce esta anomalía de un legado no liberal.

b) Un caso muy especial de la figura precedentemente examinada es el legado testamentario de alimentos debidos por ley a ciertas personas, que trataremos con independencia del carácter de asignación forzosa que le atribuye la ley. ${ }^{48}$ Se trata de una persona que sufrió en vida la declaración de estar obligada al pago de alimentos forzosos o que reconoció su deuda de tales por transacción; o que, al menos, había sido demandado para que se pronunciare tal declaración a su respecto y murió antes de la sentencia condenatoria; o, en fin, que en vida había empezado a pagar los alimentos forzosos sin previa demanda ni transacción. Con posterioridad, al otorgar su testamento, el alimentante dispone un legado con el cual ordena el pago de los dichos alimentos (supongamos, para no complicar el análisis, que en el mismo monto en que los pagaba en vida). Esta posibilidad deriva del artículo 1171 inciso $2^{\circ} \mathrm{CC}$.

Como, según quedó dicho, ${ }^{49}$ los alimentos en referencia adquieren la calidad de deuda hereditaria dejada por el alimentante, síguese que cuando éste dispone por legado su pago, tal disposición viene a ser un caso especial del legado previsto en general por el artículo 1131 CC., antes examinado; y es, en otros términos, un legado de lo debido

${ }^{47}$ Véase Guzmán Brito, A., De las donaciones entre vivos, cit. (n. 23), pp. 40-41, en donde se desarrolla el argumento - por lo demás coincidente con el sentido común jurídico- de que no dona el que paga lo que debe.

48 Véase, más arriba, el capítulo IV, 1, b).

49 Ibid. 
al acreedor (el alimentario). Lo propio hay que decir con respecto a aquellos alimentos de cuyo pago el alimentante hubiera en mora de pagarlos al morir, cuyo pago ordena en un legado.

La hipótesis de un testador que no había sido condenado ni demandado en vida al pago de alimentos forzosos, ni había transado sobre ellos, no obstante lo cual, declarándose a sí mismo deudor de tales, los dispone en su testamento, es diferente. Tal hipótesis se rige ahora por el artículo 1133 CC., pues se trata sin más de una deuda confesada en el testamento; y la disposición no constituye propiamente un legado. ${ }^{50}$

En consecuencia, el legado testamentario de alimentos que por ley se deben a ciertas personas admite el mismo doble análisis, formal y sustancial, admitido por el más general legado de lo debido al acreedor: el alimentante es libre para legar tales alimentos o no legarlos; pero si escoge asignarlos, como lo asignado era debido, ya no puede decirse con entera propiedad que el legado es liberal.

Por cierto, nada de lo dicho es aplicable al legado voluntario de alimentos (artículos 1134 y 1171 inciso $1^{\circ}$ CC.), que sin discusión de especie alguna es una asignación liberal.

\section{LUCRATIVIDAD}

En fin, se presenta la lucratividad. Con tal vocablo denotamos, como lo hemos aclarado en otro lugar, ${ }^{51}$ el carácter definitivo de una adquisición patrimonial, lo cual implica que no hay programada en ella una obligación de restituirla. Decimos, pues, que todo legado es un acto y un efecto lucrativos, en cuanto el legatario no contrae la obligación de restituir la especie adquirida, la cantidad de géneros recibida en pago, la cosa o el valor objetos de la deuda condonado o el derecho real constituido, todo en mérito de algún tipo de legado, como algo previsto en la estructura interna del acto o programado para su función.

1. No atenta en contra de este carácter, por cierto, la posibilidad de que un legado pueda extinguirse antes de morir el testador y, en especial, que éste pueda revocarlo, sea porque revoque todo el testamento que lo contenía, sea porque revoque especialmente el legado sin afectar al resto del testamento, sea porque, sin modificar formalmente el testamento, revoque por acto o hecho extratestamentario entre vivos el legado, en los casos en que uno u otro produzcan efecto revocatorio, como si cobra el testador la deuda que tenía condonada en su testamento (artículo 1229 CC.) o si enajena la especie legada (artículo 1135 inciso $2^{\circ}$ CC.) o altera sustancialmente el mueble asignado (artículo 1135 inciso $3^{\circ} 1$ CC.). Se puede añadir el caso de la revocación de una donación revocable o por causa de muerte (que es un legado anticipado), su caducidad por

\footnotetext{
50 Sobre ella, que no es un legado, véase Guzmán Brito, A. La tipología de los legados en el derecho civil chileno, cit. (n. 31), pp. 84-85.

${ }^{51}$ Véase Guzmán Brito, A. De las donaciones entre vivos, cit. (n. 23), pp. 48-50.
} 
premoriencia del donatario (artículo 1143 CC.) y la inconfirmación en acto testamentario posterior, de la donación otorgadas con las solemnidades de aquellas entre vivos con reserva de la facultad de ser revocada (artículo 1137 inciso $2^{\circ}$ CC.). En todos estos casos en que un legado normal, o un legado anticipado consistente en cierta donación revocable, se extinguen antes de morir el causante, el legatario o el donatario nada tenían adquirido aún merced a aquellos actos, debido precisamente a que las adquisiciones derivadas de ambos sólo pudieron tener lugar a causa de muerte; ${ }^{52}$ así que no puede decirse que la extinción del legado antes de la muerte de su autor afecte algo adquirido por su beneficiario, ni cabe hablar de restitución.

2. Pero bien puede acaecer que, una vez fallecido el testador o el donante por causa de muerte, y aceptada la asignación, de modo de haberse producido el efecto mortis causa que le sea propio, pierdan el emolumento ya adquirido sus respectivos beneficiarios.

a) Sin embargo, excluimos, ya preliminarmente, las hipótesis de reducción de legados, con o sin restitución para hacerla operativa, a causa de una acción de reforma del testamento destinada a restaurar la integridad de las asignaciones forzosas lesionadas en el testamento por legados dispuestos en exceso, que correlativa y congruentemente debe afectar a éstos, y que antes vimos. ${ }^{53}$ También excluimos de nuestra consideración a la reducción a que pueden verse sometidos los legados, con o sin restitución, con el objeto de hacerlos contribuir subsidiariamente al pago de las deudas hereditarias, cuando las fuerzas de la sucesión no alcanzan para cumplirlas, que también examinamos. ${ }^{54}$ Lo propio hacemos con la restitución a que puede ser obligado el asignatario de un legado modal reforzado con cláusula resolutoria, si no cumplió el modo (artículo 1090 CC.). Tales reducciones y eventuales restituciones no perturban la noción de lucratividad de los legados, porque ellas no hacen parte intrínseca de éstos y no están previstas funcional ni programadas estructuralmente para ellos. Si advienen, pues, es por causa de un accidente externo, no diferente en su configuración general a los accidentes que pueden sobrevenir a cualquier otro acto lucrativo, como la compraventa, que de todos modos está sometida a resolución por causa de incumplimiento de sus obligaciones, sin que por ello la compraventa, como tipo, deje de ser lucrativa.

b) También excluimos las hipótesis de restitución de lo legado por causa de incapacidad o indignidad del legatario (artículos 967 y 974 CC.), por la misma razón de ser una causa extrínseca a la figura la que provoca la restitución.

c) Distinto aspecto ofrecen los que podemos llamar legados con causa onerosa que no puede estimarse en dinero. La figura no ha sido considerada por la doctrina, la cual

52 Si el autor de una donación revocable entregó en vida el goce de lo donado al donatario (artículo 1140 CC.), o si el testador entregó en vida el goce de lo legado al legatario (artículo 1141 inciso $2^{\circ}$ CC.), ni el uno ni el otro adquieren el dominio de lo donado o legado, sino sólo los derechos de usufructuario y contraen sus obligaciones (artículo 1140 inciso $2^{\circ}$ CC.). Pero ya sabemos que este efecto entre vivos no proviene de la donación revocable o del legado sino de la ley: véase, más arriba, III, a).

53 Véase, más arriba, IX, 3.

${ }^{54}$ Véase, más arriba, IX, 4. 
sólo ha tratado, y tangencialmente, de otra que el Código menciona en tema de contribución subsidiaria de los legatarios al pago de las deudas hereditarias, en su artículo 1367, y denomina "legados con causa onerosa que puede estimarse en dinero". El Código propiamente no define qué entiende por tal; pero se ha interpretado, ${ }^{55}$ y con razón, que bajo aquella denominación se abraza al llamado sublegado, nombre éste que esconde al legado mandado pagar por el testador a un legatario, cuya posibilidad emana de los artículos 1360 y 1364 CC.; y al legado modal (\$ 4 del título $4^{\circ}$ del libro III CC.).

Ahora bien, como el artículo 1367 CC. habla de "legado con causa onerosa que pueda estimarse en dinero", nosotros inferimos que él considera la posibilidad de un legado con causa onerosa que no pueda estimarse en dinero. La dicción del artículo 1543 del "Proyecto de 1853", 56 antecedente directo del actual artículo 1367 CC., expresamente aludía a ella. Que se haya suprimido su mención en el Código no implica que no exista o sea inaceptable para la ley. Eso, a lo más, puede conducir a establecer discriminaciones apropiadas en lo tocante el tema de las deducciones de lo invertido en el gravamen no pecuniario, a efectos de la responsabilidad subsidiaria de los legatarios frente a las deudas hereditarias; pero no permite, insistimos, negar validez a la figura en sí. Por lo demás, que un testador pueda disponer un legado con causa onerosa que no pueda estimarse en dinero es totalmente admisible merced al artículo 1069 CC., en la medida en que nada de su disposición vulnere los requisitos o las prohibiciones legales; ello obliga a examinar su consistencia dogmática.

Un legado con causa onerosa que no puede estimarse en dinero es correlativo de la donación con causa onerosa que el Código regula en su artículo $1404 .^{57}$ Se trata, en efecto, de donaciones con causa onerosa que no puede estimarse en dinero: "[...] como para que una persona abrace una carrera o estado, o a título de dote o por razón de matrimonio", ejemplarización en el todo coincidente con la que ofrecía el artículo 1543 inciso $2^{\circ}$ del "Proyecto de 1853" para los legados con causa onerosa no apreciable en dinero: "No es causa onerosa apreciable en dinero el destino del legado al establecimiento del legatario en matrimonio, o en una profesión u oficio, o a otros objetos análogos [...]”.

Puesto que nosotros hemos hecho objeto de un estudio especial y aparte al legado con causa onerosa no apreciable en dinero, ${ }^{58}$ omitiremos desarrollar su completa configuración aquí, y tan sólo nos limitaremos a explicar lo necesario, en orden a hacer ver por qué tal legado ofrece problemas de lucratividad.

El punto es que el legatario no está obligado a realizar la causa onerosa prevista en el legado, por ejemplo, a casarse, o a ordenarse sacerdote o a permanecer en viudedad, cuando tiene hijos de antecedente matrimonio (argum. ex artículo 1075 CC.), etcétera; pero si no realiza la causa, debe restituir el emolumento del legado al interesado en él,

${ }^{55}$ Por todos: Domínguez, R. \& Domínguez, R., Der. suc., II, núm. 857, p. 849.

${ }^{56}$ En Bello, A., Obras completas de don [...], Santiago, Pedro G. Ramírez, 1888, XII: Proyecto de Código Civil (1853), p. 366.

57 Sobre las donaciones con causa onerosa, véase Guzmán Brito, A., De las donaciones entre vivos, cit. (n. 23), pp. 215-220.

${ }^{58}$ Guzmán Brito, A., El legado con causa onerosa que no puede estimarse en dinero (en prensa). 
vale decir, normalmente al heredero, quien dispone, por consiguiente, de una acción personal de restitución. ${ }^{59}$ En tales circunstancias, el efecto pecuniario producido por el legado queda entretanto como acreditado en el legatario: es suyo, pero lo debe, hasta que se efectúa la causa. ${ }^{60}$ Ofrezcamos un ejemplo: en esquema, un testador dispone: "Lego el fundo Corneliano a Ticio para que se reciba de arquitecto", lo cual realmente se puede decir también de varias otras maneras, por ejemplo: "y le impongo la carga (o el gravamen, o la causa onerosa) de recibirse de arquitecto"; o: "con el fin de que se reciba de arquitecto", etcétera. Se trata de un legado de especie con efecto real, que hace dueño de ésta sin más al legatario; el cual, empero, no lucra de inmediato con la especie, atendido que, desde el momento mismo en que adquiera su dominio, la empieza a deber al heredero.

El descrito efecto del legado en examen ciertamente le resta lucratividad inmediata, porque la adquisición inicial del legatario no es definitiva, por el mismo hecho de ser debido el emolumento de la asignación en tanto penda el cumplimiento del gravamen previsto en ella. Solo desde que éste se cumple, la adquisición se torna en definitiva y exclusivamente entonces el legatario empieza a lucrar. Si no llega a cumplirse, procede la restitución y el legatario no lucra de manera irreversible. Ahora bien, esta ausencia inicial y temporal de lucratividad no es algo extrínseco al legado, ni accidental o contingente, sino inherente en él, porque la restitución está prevista en la estructura interna del acto y programada por su función, a diferencia de cuanto ocurre en otros eventos de restitución, como vimos; y por más que, en el designio funcional del testador, no sea la restitución el centro de su asignación.

Tal configuración resulta algo semejante a la del cuasi-usufructo dispuesto merced a un legado, que pasamos a estudiar.

d) La última figura con problemas de lucratividad es precisamente el legado de un cuasi-usufructo.

Como es sabido, de la figura general, aunque sin designarla como aquí hemos dicho, trata el artículo 789 CC.: "Si el usufructo se constituye sobre cosas fungibles, el usufructuario se hace dueño de ellas, y el propietario se hace meramente acreedor a la entrega de otras especies de igual cantidad y calidad, o del valor que estas tengan al tiempo de terminarse el usufructo". Por otro lado, la posibilidad de constituir un usufructo de fungibles o cuasi-usufructo por testamento deriva del artículo 766 N 2 CC. Supongamos, pues que alguien dispone así en su testamento: "Lego el usufructo de 1.000 a Ticio". Al hacerse operativo

${ }^{59}$ La causa onerosa no actúa como condición suspensiva del dominio de la especie o de la titularidad del derecho real legados, o del crédito conferido por el legado de género, o de la condonación otorgada por el legado de remisión, etcétera; ni como condición resolutoria ordinaria de lo mismo ganado. El legado, pues, no se asigna bajo el esquema: "lego si [...]" ni "lego hasta que [...]", sino: "lego para [...]". Por lo mismo, si este legado es de especie, no debe confundírselo con un fideicomiso de especie.

${ }^{60} \mathrm{Si}$, por ejemplo, el legado fue de especie, el legatario la adquiere, pero la debe; si fue de un género y se lo pagó, el legatario adquiere la cantidad, pero la debe; si consistió en la constitución de un derecho real, por ejemplo, de un usufructo, lo adquiere el legatario, pero debe devolverlo (por renuncia). Si el legado consistió en la condonación de cierta deuda, ésta se extingue, pero el legatario sigue debiendo su objeto, aunque ahora a título de legado. Al subseguir la carga, el legatario deja de deber en todos los casos. 
este legado, Ticio, el legatario, puede reclamar 1.000 al o a los herederos gravados con el legado, mediante la acción personal del testamento, pues, por su naturaleza, un tal legado no puede producir efecto real. Una vez que la cantidad le sea entregada, Ticio se hace dueño de ella, como lo dice el artículo 789 CC. citado. Pero el o los herederos gravados se hacen acreedores de la misma cantidad, cuya devolución podrán exigir -como también lo dice la norma- al extinguirse el usufructo por cualesquiera de las causas generales de extinción del mismo, que sean aplicables a la figura en examen, ${ }^{61}$ sea al cuasi-usufructuario, sea a su heredero. En consecuencia, el legatario no lucra con la cantidad cuasi-usufructuada a él, porque la debe. Más aún, tal ausencia de lucratividad es permanente, pues la cantidad de fungibles siempre ha de ser devuelta. ${ }^{62}$ Así que, en términos sustanciales, dicho legado no es propiamente tal, sino en sentido formal.

Para terminar, volvamos brevemente sobre el legado con causa onerosa en comparación con el que acabamos de tratar. Sin hacer caudal de diferencias accidentales, la decisiva entre ambos radica en que la deuda emanada del cuasi-usufructo ofrece la permanencia normal de cualquier deuda, hasta su pago, por cierto, o extinción por otras causas generales; mientras que la derivada del legado con causa onerosa que no puede estimarse en dinero en primerísimo lugar está destinada a extinguirse, no por el pago u otra causa general de extinción, sino por el advenimiento de la causa onerosa. Pero, en el hecho inicial, de que una vez adquiridos ambos legados el legatario debe lo recibido, hay completa semejanza.

\section{BIBLIOGRAFÍA}

Bello, Andrés, Obras completas de don [...], Santiago, Pedro G. Ramírez, 1887, XI: Proyectos de Código Civil.

Bello, Andrés, Obras completas de don [...], Santiago, Pedro G. Ramírez, 1888, XII: Proyecto de Código Civil (1853).

Claro Solar, Luis, Explicaciones de Derecho civil chileno y comparado, XV: De la sucesión por causa de muerte, 1942, reimpresión Santiago, Editorial Jurídica de Chile, 1992, VII.

Domínguez Benavente, Ramón - Domínguez Águila, Ramón. Derecho sucesorio, $2^{a}$ edición, Santiago, Editorial Jurídica de Chile, 1998.

Elorriaga de Bonis, Fabián, Derecho sucesorio, Santiago de Chile, LexisNexis, 2005.

Guzmán Brito, Alejandro, De las donaciones entre vivos. Conceptos y tipos, Santiago, LexisNexis, 2005.

- Derecho privado romano, Santiago, Editorial Jurídica de Chile, 1996 y reediciones posteriores, dos volúmenes.

${ }^{61}$ Véanse los artículos 804 y 806 CC. (causas primera, y tercera a quinta). La segunda causa descrita en ese artículo y las demás establecidas en las disposiciones siguientes del Código no son aplicables.

${ }^{62}$ El usufructo de fungibles en realidad no es un usufructo, sino una figura crediticia que se rige por ciertas reglas del usufructo. Cuando reviste la forma de un legado-el equivalente mortis causa de un mutuo-, uno de sus efectos es, sorprendentemente, convertir directamente en deudor al legatario, aunque, por cierto, tal no sea su función ni su fin práctico. Hay otros legados que también imponen deudas al legatario, mas por vía accesoria, como el legado modal. 
- "La tipología de los legados en el Derecho civil chileno", en Revista de Derecho de la Pontificia Universidad Católica de Valparaíso 27, Valparaíso, 2006, Semestre I, pp. 51-85.

Meza Barros, Ramón, Manual de la sucesión por causa de muerte y de las donaciones entre vivos, $8^{a}$ edición, Santiago, Editorial Jurídica de Chile, 2007.

Rodríguez Grez, Pablo, Instituciones de Derecho sucesorio, 2ª edición, Santiago de Chile, Editorial Jurídica de Chile, 2002.

Somarriva Undurraga, Manuel, Derecho sucesorio, $6^{a}$ edición, Santiago, Editorial Jurídica de Chile, 2003. 